\title{
Exploring New Ways of Communicating CSR to the Relevant Stakeholders: An Empirical Study
}

\author{
Mohammad Abul Bashar ${ }^{1}$ \\ ${ }^{1}$ Associate Professor \& PhD Fellow (2016-17), Department of Management, Faculty of Business Administration, \\ University of Chittagong, Chittagong, Bangladesh \\ Correspondence: Mohammad Abul Bashar, Department of Management, Faculty of Business Administration, \\ University of Chittagong, Chittagong- 4331, Bangladesh.
}

Received: May 7, 2020

Accepted: June 30, 2020

Online Published: July 1, 2020

doi:10.5430/bmr.v9n2p25

URL: https://doi.org/10.5430/bmr.v9n2p25

\begin{abstract}
A flower must be pollinated properly to produce seeds as final outcome of next germination to create new flowers and so on. Accordingly Corporate Social Responsibility (CSR) actions and practices of an enterprise should be communicated with its stakeholders. CSR and CSR communication should go hand-by-hand. The recent business trend shows that businesses are becoming increasingly aware of CSR and CSR communication systems. Existing studies, firm's case study and real world phenomenon also reveal that business houses and society are benefiting from CSR actions and communicating those with their stakeholders. This research explores CSR and CSR communicating strategies and finds that stakeholders have in-depth concerns about CSR. It's interesting that popular CSR practices like charity and philanthropic actions have been replaced by environmental (carbon footprint, air and water pollution), legal (complying regulatory imperatives) and ethical (promoting corporate ethics, norms and values) etc. Moreover, the study also shows that communicating CSR actions through CSR reporting, company annual reports or firm's sustainability reports and advertising have become less fashionable means of exchanging CSR efforts while academic books (companies are cited as examples or extracted as referred case studies), newspaper, internet and third party (social, political, local government authorities) association have become more trusted ways of communicating CSR motives, practices and actions.
\end{abstract}

Keywords: Corporate Social Responsibilities (CSR) and CSR Communicating Tools and Techniques, CSR Perceptions and Attitudes

\section{Introduction}

Corporate Social Responsibility ( CSR) has paved the significant avenue to integrating social, environmental, ethical and human rights concerning into business operations and has been recognized as a vital approach of influencing stakeholder relationships (Gardberg and Fombrun, 2006). Consequently, for the companies to achieve the symbiotic relationships through their CSR activities and efforts, they must communicate them to the relevant stakeholders and groups in a strategic ways (Dawkins, 2004). Morsing (2018) argues that despite the CSR communication matters strategically and importantly for business as well as society CSR scholarly discourses are not yet assuming CSR communication from superior perspectives (but "just talking") of actions as well as decoupled from social obligations, impacts and influences. But businesses and society are tied together in a relationship of co-existence (Davis, 1985) and inevitably complementary to each other (Drucker, 1948). Robins (2005) and Chandler (2016) argued that the recent business trend is not only concentrating the profits but also the interests like shared value $\&$ welfare of the society. Post et al (2002) and Falck and Hebich (2007) consistently argues with Robins (2005) putting importance of business prosperous survival by accepting society oriented non-economic-actions like social welfare, and thus, companies can harvest positive returns (Falck and Hebich, 2007; Lim \& Greenwood, 2017), otherwise business survival is endangered (Post et al., 2002). Robbins and Coulter (2012: 124) appealed that companies have no exceptions of complying social obligations and furthermore, they should be increasingly concerned for social responsiveness and social responsibility. Impacting research evidences suggest that by contributing to societal welfare, firms can definitely enhance their corporate image among its stakeholders--in particular, its customers (Sacconi, Blair, Freeman and Vercelli, 2011) and many companies today are integrating CSR strategically into their brand communications (Morsing, 2018). Morsing ( 2018) also emphasized that whatever the reasons in behind the practices of CSR by the business houses but CSR 
communication is vital for paving the way they engage in communication about CSR which is absolutely central for how they are perceived by others to contribute to the society.

For CSR to generate goodwill, consumers generally need to perceive a fit between the sponsoring firm and its CSR. Otherwise, consumers may second-guess the firm's intrinsic CSR motives, which may even evoke a negative reaction. In practice, however, many firms today engage in CSR activities that cover a wide spectrum of perceived fit. To this end, research by Sohn et al. (2012) explored communication strategies (elaborationalvs relational) that help elevate the perceived fit between the sponsoring firm and its CSR activity at high vs. low levels. Specifically, they found elaborational communication strategy (which focuses on the merits of CSR activity per se and not on the association with the firm) to be more effective for the low-fit case, whereas relational communication strategy which highlights the association between the company and CSR was more effective for the high-fit case (Sohn et al., 2012).

Numerous, except the school of Friedman (1970) views, authors in their researches logically articulated that the business enterprises should respond in tying deeper bond to the society where they operate businesses and live with. In this connection, it is to be mentioned that although corporate social responsibility is a widely recognized concept yet the business firms are found to respond to it differently. Research indicates that CSR is one of the ways through which corporations can respond and communicate to economic, social, and environmental stakeholders' interests. This paper lays the groundwork to investigate the issue from both primary and secondary sources of data analysis.

\subsection{Background of the Study}

Carroll (1998:1) raised a question of key CSR concentration "What can business expect second option of not being a good corporate citizen?"The inter-actions, interrelations and interdependencies between society and business are also well researched and accepted phenomenon by the authors, practitioners, researchers and academicians. A business has different stakeholders such as shareholders, suppliers, customers, competitors, employees, government, financial and investment institutions, and a society as a whole. These stakeholders are interlinked to the business anticipating diverse set of interests and goals such as profit or dividends, interest, salaries, wages and fair compensation, quality and products at fair price, rational/ profitable prices, total welfare, taxes and more social goods rather commercial commodity etc. (Garrett and Klonoski, 1990; Alam, 1996; Jensen, 2001; Lamy, 2002; Timmins, 2004 and Robbins and Coulter, 2012). Therefore, Gossling and Vocht (2007) emphasizes that businesses should not only address the economic goals but social and ecological goals and simultaneously stakeholders' expectations as well as not to forget giving something back to the society where it operates its business. Famous economists like Smith (1776) and Schumpeter (1911) argue that business receives resources from the society and responsible for the development of society as per as the nation.

Du et al (2010) clearly demonstrates that doing social welfare is not a cost for the businesses at all, because business can benefit from CSR actions by communicating those with its stakeholders and society at large. They argued benefits like organizational reputation, brighter image, customer's loyalty and words-of-mouth of consumers. However, the reviewed literature indicates that effective CSR communication strategy is still under researched area (Kim, 2011). Moreover, views and expectations of stakeholders are altering day by day. Business should understand the pattern and shape of these changes in order to undertake CSR actions correspondingly (Kim, 2011). Since the organizations today are recognizing the necessity to fit into placing CSR and sustainability endeavors, it is also integrated to succeed in communication that they are doing so (Brunton et al., 2017). The study, therefore, accepts the topic and endeavors to find the best CSR practices and ways to communicate those with the stakeholders.

\subsection{Problem Statement}

If an organization's CSR policy or implementation method has a direct effect on a particular stakeholder group, this organization will be tremendously affected by how this stakeholder group evaluates it. According to the stakeholder theory, the relationship between an organization and its stakeholders is dynamic, and all the parties involved in this relationship are interdependent and interrelated regarding damages, interests, obligations, and rights (Freeman, 1997: Freeman et al., 2010). Moreover, CSR can be straightforwardly understood as the formal recognition at corporate governance level of the obligations owed to all the stakeholders because they are legitimate sources of ends for corporations (Donaldson and Preston, 1995; Sacconi, Blair, Freeman and Vercelli, 2011). The research topic is, therefore, attracted great attention and aims to explore CSR engagements of the business enterprises. Research indicates that CSR activities, if successfully and effectively communicated with stakeholders, can be resulted into positive key result areas such as increased customer's loyalty, favorable reputation, brand loyalty, intrinsic motivations among both internal and external stakeholders etc. 


\subsection{Research Rationality}

Research shows that CSR is not an entirely new notion in the domain of corporate activities. Back in the 1930s the idea that public companies were fiduciaries of constituencies much broader than shareholders was put forward and widely discussed as one of the possible interpretations of the very reason for the large corporations' existence (Sacconi, Blair, Freeman and Vercelli, 2011; xv). In his earlier writing Berle (1931) (as cit. by Aoki in Corporations in Evolving Diversity, 2010) maintained that corporate powers were held in trust not only of the corporation per se but also for individual members of it (Berle, 1931). Dodd (1932) challenged this view by arguing that the directors of a corporation must (if they had not already) become trustees not merely for shareholders but also for other constituents of corporations, such as employees, customers, and particularly the entire community (Aoki, 2010: 15). Social and academic researches exploring the value of CSR are growing day-by-day. Some researches indicate that CSR has no impact on economic and financial performances of business (Page \&Fearn, 2005). On the contrary, various researches (David, Kline, \& Dai, 2005; Kim, Haley,\& Schumann, 2009; Lim \& Greenwood, 2017; Brunton et al., 2017 etc.) argue that there's a esteemed relationship between CSR and firm's performance as well as stakeholders' perceptions specially consumers, suppliers and society as a whole. Moreover, Amaladoss and Manohar (2011) argue that whatever the ranges of CSR actions and activities like charity or other social welfare, those don't bring any favorable blow i.e. benefits for the firm unless those are communicated in an impacting ways. This empirical research, therefore, originates high degree of rationality in studying CSR communication. Therefore, inevitably, today CSR has become more and more a global issue rather local. Business and society are aiming to be tied into a symbiotic relationship rather parasitic relationship through responding stakeholders' interests properly. Hence, the issue raised a burning management question as follow;

\subsection{Management Question}

In what ways CSR can help firms engaged with stakeholders by responding to their interests through effective communication strategies and develop new CSR strategies

\subsection{Aims of the Study}

The aim of this research is set ahead of the specific set of research objectives below. Drucker (1984) argues that the firms have addressed the CSR issues and managers should comply with those through their decisions and behaviors. Freeman et al (2011) argue consistently to this phenomenon that in order to understand a business, it should be viewed as a holistic set of relationship through communication with various stakeholders like investors, shareholders, bondholders, stockholders, customers, employees, competitors etc. So the study endeavors to identify the means of practicing CSR and ways of communicating with the stakeholders.

\subsection{Objectives of the Study}

This research is aimed to achieve the following set of measurable, achievable and specific objectives.

- To explore CSR communication strategies and evaluate effectiveness of CSR communication strategies

- To develop CSR policy recommendations for sustainable tie in between society and business world

\subsection{Research Questions}

In order to achieve the objectives the following research questions are derived which correspondingly orchestrate the research topic.

- How do CSR communication strategies help companies engage with stakeholders responding to their interests?

- What CSR policy recommendations for sustainable tie in between society and business world can be put forward?

\section{Literature Review: Theoretical Perspectives}

The historical background shows that Corporate Social Responsibility (CSR) is not a new business philosophy and received focal attention about fifty years ago (Carroll, 1999), and now it's attracted greater attention of the global economy in an increasing way and firms have started to accept CSR as an input along with the profit considering long term strategic implications of CSR (Morrison \&Bridwell, 2011:144). These propositions are highly cohesive to the argument by Brown (2001) that firms can't ignore the accountability and responsibility to the society. Therefore, the conceptual research reflects the idea that organizational behavior is a potential key to the promotion of societal goals, including the achievement of governmental (national or international) strategies on sustainable development (Graafland\& Schouten, 2012). There is neither any unanimous definition of CSR nor universally accepted 
phenomenon. Various authors like Clarkson (1995), Jamali and Mirshak (2007) and Castka and Balzarova (2008) described it as obligations of business to the society and stakeholders so that their demands are met in corresponding to their expectations. While McWilliams and Siegel (2001) defined it as a process of involving in the social actions which are not core interests of the firm but the feel of obligations. WBCSD (2000) defined CSR as a series of firm's actions which are dedicated to ensure ethical, economic, quality and quantity of social life including employees aiming the greater impact to both local community and society as a whole. While Gainer (2010) views it as a movement of corporations and the ideas behind it are firm's practices should reflect social goals sufficiently. However, the definitional questions on strategic CSR, philanthropic CSR and coerced CSR are still unsolved (McWilliams and Siegel (2001). Corporate social responsibility (CSR) is viewed by the authors, academicians and researchers from further perspectives. For instances, according to Carroll $(1983 ; 608)$ "CSR involves the conduct of a business so that it is economically profitable, law abiding, ethical and socially supportive". Kotler and Lee (2005) views CSR as the commitment of business to the society and the commitment is fulfilled through the discretionary business actions and organizational resources. Late recent, CSR is optimized as the route of creating shared value (instead of profit maximization) through company policies and practices that increases the competiveness of company while simultaneously improving the economic and social conditions of the community in which it operates ( Porter and Kramer, 2011; Chandler, 2016). However, Friedman (1970 and 1962) and Levitt (1958) view CSR from direct opposition that CSR of business is "Earning only profits for shareholders" and "Doing welfare of the society is government's responsibility" respectively.

\subsection{Approaches to CSR}

Like the lack of definitional congruency approaches to CSR also represent different faces of CSR. For instance, Basu and Palazzo (2008) demonstrated three approaches of CSR they are stakeholder, performance and motivation driven CSR. On the other hand, Robbins and Coulter (2012) have divided the CSR into three major perspectives like social obligations (meeting mandatory social imperatives such as ensuring product safety, consumer's rights), social responsiveness (meeting some popular social needs like welfare, charity etc.) and social responsibility (e.g. technology stewardship - greening technology). While Carroll's Pyramid (1991) shows four viewpoints of CSR such as philanthropic - undertaking community projects, ethical - ensuring good governance and ethics, legal - to complying legal imperatives and economic - creating employment opportunity, undertaking investment portfolios and paying tax.

\subsection{Value of CSR}

Reviewed literature shows that consumers favor more to CSR practicing companies than those who don't (Sen and Bhattacharya, 2001 and employee or labor commitment to the organization is related to the perceptions of their firm's social responsibility (Brammer et al., 2007; Harvey et al., 2017); prospective employees are more attracted to more socially responsible corporations (Greening and Turban, 2000); and investors often prefer socially screened investment funds (Stone, 2001). Therefore, these various groups of stakeholders, together with other interested parties may play a crucial role in stimulating and pressing corporations to engage in socially responsible practices in different domains (Duarte, Mouro and Neves, 2010).

\subsection{CSR Stakeholders' Expectations}

The stakeholders of business are diverse such as customers, shareholders, investors, competitors, government, suppliers, financial and investment institutions etc (Holme\& Watts, 2000) and stakeholders interests are reversed to firms goals and objectives ( Kumar \& Subramanian, 1998) for instances, consumers want best product at low price which is opposite to the firms' profit orientation. A recent research on stakeholders' expectations conducted by Popoli (2011) reveals that stakeholders are varied on the basis of their CSR expectations. These expectations are neither similar nor specific to a particular group and pervasive among all of them. While Whitehouse (2006) and Balmer and Greysner (2006) consistently argue that the range of CSR expectations among the stakeholders are not only augmenting but also persistent everywhere and firms should address the issue proactively rather than being reactive Harrison and St.John (1996) emphasizes that recent business environments have been changed and stakeholders should be managed very carefully and strategically. "The varied expectations of stakeholders about a company's social responsibility paint a complex picture of multidimensional social responsibility factors, which are linked to economic, environmental and social issues" (Popoli, 2011). The Following figure illustrates the 'everywhere' presence of CSR expectations (Popoli, 2011). 


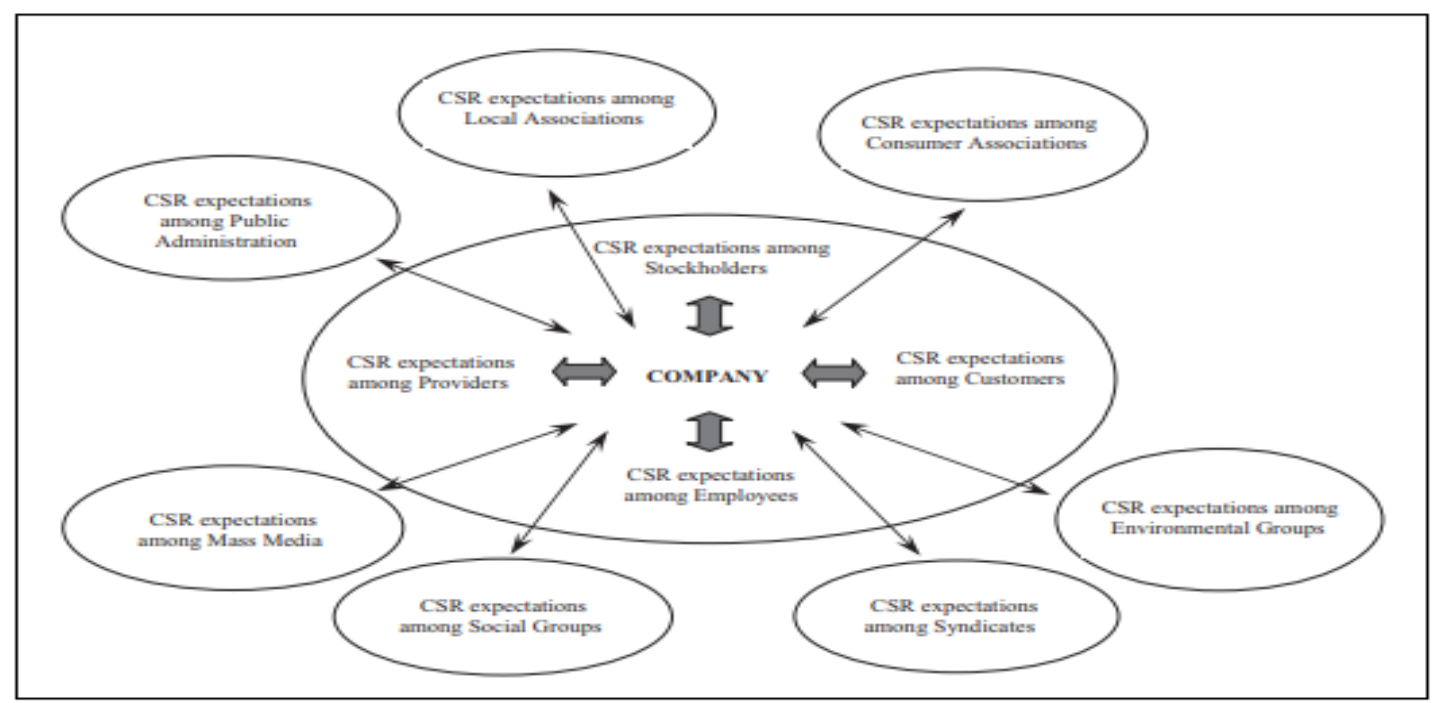

Figure 1.Linking CSR Strategy and Brand Image Different Approaches in Local and Global Markets, SAGE Publication.

Source: Popoli, P. (2011). Retrieved from www.sagepublications.com

\subsection{A Theoretical Debate}

The classic research in the late $60^{\text {th }}$ decade by T. Levitt (1958) put CSR in dichotomy that doing social welfare is not a business of the enterprises while this responsibility goes to the state or government. In the next decade in 1970s Milton Friedman made the debate more scorching by arguing that firm's sole responsibility is to generate profit for the shareholders not doing good for the society because such contributory actions will make business institutions powerful. He also argued that if shareholders' interests are preserved they can contribute to the society by further investments and thereby economic emancipation. Morrison and Bridwell (2011) participated in the group of CSR antagonists a bit carefully and said that CSR encourages unrealistic demands among the stakeholders that might divert ultimate goals and objectives of business; hence CSR should be excluded from the definitional domain of business.

Moreover, the reviewed research reflections on the studies by Brammer and Millington (2004), Kakabadse et al (2005), Lydenberg (2005) and Matten and Crane (2005) reveal that CSR accountability might be risky, organizational conflicts could be stimulated due to power struggle among the stakeholders, CSR is still clumsy and complicated concepts to the researchers, CEOs and practitioners. A recent research by Dincer (2011) reveals that the shareholders of the organizations may confront the CSR if it negatively impacts the firm's financial performance while, still the employees perceive it positively. Another contemporary research by Marais (2012), contradicts to the research findings by Sen and Bhattacharya (2001), reveal that CSR commitment might create no appeal among the customers because of least sensitivity.

\section{CSR Communications: Theoretical Paradigm}

\subsection{Conceptual Framework}

The growing power and influences of communication is eminent today and it has become an effective tool to manage and engage with the stakeholders effectively (Windell, 2006). Conceptually CSR communication means to a company's attempt for exchanging CSR efforts with its stakeholders and CSR communication embraces - agendas and issues of CSR, challenges and debates, stakeholders' understandings towards company's contribution to the community and, thus setting a landscape for directing future CSR activities or policy frameworks ( Morsing, 2018). CSR communication is also referred by Morsing (2006:171) as "communication that is designed and distributed by the company itself about its CSR efforts". Ihlen et al. (2011) defines as organizational communication systems which ensure responses to the various impact issues like economic, social and environmental practices. Morsing and Schultz (2006) refer to three basic types of CSR communication such as 'stakeholder-information-strategy', 'stakeholder-response-strategy' and 'stakeholder-involvement-strategy. However, Du et al. (2010) argues that most forms of CSR communication basically conveys the firm's CSR commitments and involvement of corporate causes 
but residing away the social cusses. Thus, we can define CSR communication as a process of designing and maintaining an environment that facilitates exchanging of CSR facts and data, ideas and views, thoughts and efforts, and disseminating CSR actions with the stakeholders.

Today organizations are under pressure to disseminate or diffuse the information at a large scale to the stakeholders (Gray et al., 1996) which has made CSR communication mandatory for the senior executives and managers of the organizations ( Prado-lorenzo\& Garcia-sanchez, 2010). Arvidson (2010) emphasizes that CSR communication has become a significant avenue to uphold both corporate and managerial legitimacy. A recent research by Perks et al. (2013) reveals that stakeholders are increasingly expecting the firms to be engaged in socially responsible efforts and communicate those with them, and organizations are doing it toward the influential stakeholders groups effectively through CSR communication ( Porter \& Kramer, 2011). Firms can construct an impressive communication system of recognized communicating motives i.e. extrinsic and intrinsic motives of communication, thus organizations can avoid stakeholder's skepticism, defined the validity and credibility of the message and uphold the reputational goodwill (Grier, 2003). Furthermore, in the latest recent Ferreira \& Ribeiro (2017) strongly argued that corporate social irresponsibility (CSIR) negatively affects consumer behavior such as consumers' willingness to pay and purchase. However, recently Cho et al., (2017) found that "corporations communicate noncorporate social responsibility messages more frequently than corporate social responsibility (CSR) messages which may reflect public cynicism of CSR communication". Eventually, companies can ensure favorable repercussion of the customers by being engaged and communicating CSR actions while the repercussions are resulted into multi-facet returns like attracting skilled human resources, brand reputation and lucrative investors (Sen et al., 2006; Morsing, 2018).

The comprehensive conceptual framework of CSR communication has been proposed by Du et al. (2010) that exhibits two set of CSR communication outcomes i) internal outcomes i.e. awareness, attribution, attitudes, identification and trust ii) external outcomes i.e. consumers - purchase, loyalty, advocacy; employees productivity, loyalty, citizenship behavior and advocacy, investors - amount of invested capital, loyalty. The model is depicted below.

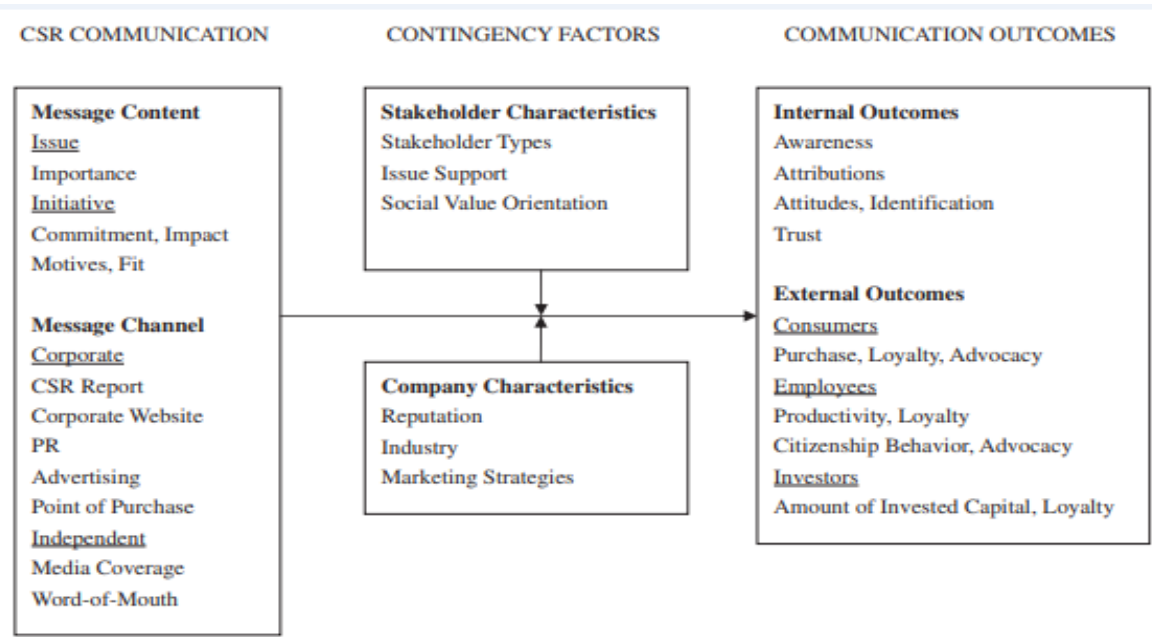

Figure 2.Maximizing business returns to corporate social responsibility; The role of CSR communication: Source:

Du, S., Bhattacharya, C. B. and Sen, S. (2010), International Journal of Management Reviews, vol. 12 no.1, p. 11

The impacting study by Sora Kim (2011) has tested the consumer's response model of two famous companies Kellogg and Motorola and developed a synergistic model of corporate communication. The model demonstrates that popular companies (for example Kellogg and Motorola) can conveniently exert influences over the customer's product evaluation through performing and communicating CSR efforts to them. Takano (2017) examined Kikkoman's ( an internationally recognized soya sauce maker) CSR communication with public schools in Japan and found that the company effectively captured the previously untapped market of Japanese public schools as well as company's corporate image is upheld using the vehicle of CSR practices. On the other hand, Drumwright's (1996) model proposes three different organizational campaigns such as economic campaigns, non-economic campaigns and mixed campaigns in the marketplace and found same outcomes like Takano ( 2017) and Sora Kim (2011). Popoli (2011) emphatically argued that the business houses can position brand images if they are able to satisfy the stakeholders' expectation in a meaningful and value creating ways and correspondingly can communicate such efforts to the 
stakeholders. Consequently, companies can gain trust, credibility and reputation onward positioning brand strength in the market (Erdem\&Swait, 2004), as a resultant impact on company's competitive advantage and profitability (Porter, 1985). Popoli (2011) conceptualized the above phenomenon in the following figure.

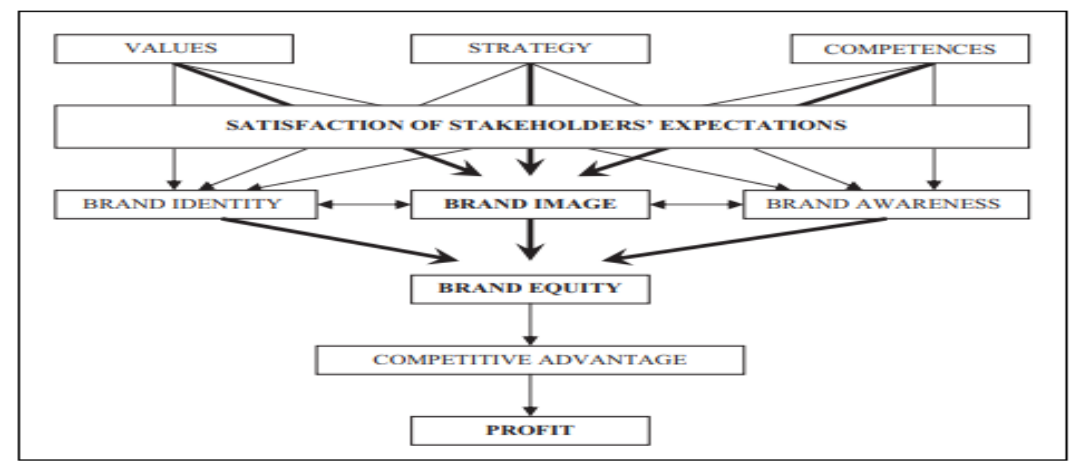

Figure 3.Linking CSR Strategy and Brand Image Different Approaches in Local and Global Markets, SAGE

Publication; Source: Popoli, P. (2011). Retrieved from www.sagepublications.com

\subsection{CSR Communications: Legitimacy, Channels and Strategies}

Research evidence suggests that the more the companies are upholding their reputations and opportunities the higher they are motivated to be aligned with the stakeholders' expectations through the CSR practices and actions (Dawkins, 2004). However, Enron, Royal Dutch Shell and Walmart's bright images were darkened due to corporate scandals (Stuart, 2006). So the term Legitimacy comes forward. According to Lindblom (1994), "Legitimacy is a condition or status which exists when an entities value system is congruent with the value system of the larger social system of which the entity is a part. When a disparity, actual or potential, exists between the two value systems, there is a threat to the entities legitimacy". Brown and Deegan (1998) argue that the theory of legitimacy finds the ways to ensure congruency between social values, norms and ethics and those of the societies in which they operate. Deegan (2002) and Elsbach (2003) discloses a bleak truth that organizations use CSR as a tool of social impression management and Elsbach (2003) also argue that they do it using various techniques like categorizations, verbal accounts, symbolic markers or representational behavior.

Lindblom (1994) argued that companies basically use four different kinds of legitimacy strategies to communicate social and public's pressure. These strategies are i) Firms are intended to inform the stakeholders about the organizational performances ii) an attempt of status quo i.e. trying to change stakeholders' viewpoints yet corporate behavior is unchanged iii) a diversion strategy which seeks to focus on a positive activity not linked with the realities and iv) a final strategy is to alter stakeholders' expectations about the organizational performances. On the other hand, Cho (2009) finds that organizations use image enhancement (e.g. self praising information), avoidance (converting focus from social and environmental aspects to other viewpoints) and disclaimer (refusing or denying any negative consequences) strategies to communicate with stakeholders.

Research indicates that organizations should be aware of selecting channels or media to convey messages about CSR efforts and activities to the stakeholders. A KPMG (2008) survey shows that organizations $80 \%$ of the global leading-edge companies produces CSR reports as an effort to communicate CSR attempts and endeavors to the stakeholders. Du et al. (2010) have suggested some influential channels for communicating firm's CSR endeavors to the stakeholders - official documents, annual CSR reporting, press releases, TV commercials, various magazines, outdoors advertisements, product labeling and packaging, and a dedicated CSR website are dominant channels proposed by Du et al. (2010).

\section{Research Methodology}

\subsection{Research Design}

Trochim and Donnely (2007) recognizes the research design as 'the glue' that helps the whole research projects developed in an expected way i.e. consistently by keeping the parts of the research together. On the basis of nature of study problems, research questions and to satisfy the objectives of the study this research is designed to cover the exploratory, descriptive and causal analysis. The survey research method will be the basic research design. Moreover, focus group, case study and interview will serve the purpose of qualitative data sources. 


\subsection{Sample Design: Sources of Primary Data}

The stratified sampling is the basic sampling technique in this research. For the purpose the entire target population is divided into four different subgroups, or strata, and then randomly selected the final subjects proportionally from the different strata. Approximately 60 individuals (Managers and Executives-15, Social and Political Leaders-15, corporate entrepreneurs and CEOs- 15, researcher and academicians- 15) from different national cultures are surveyed or interviewed. The Focus study also is an esteemed primary source of data.

\subsection{The Desk Study: Sources of Secondary Data}

An extensive desk study is conducted to have an idea about CSR and CSR communication issues, areas, practices models, impacts and factors etc. for the development of an extensive literature review. This enriches the study to develop theoretical background of the study. Moreover, the desk study has been aimed at identifying the policy documents that have already been published and researched in the different parts of the globe covering the issues of Corporate Social Responsibility (CSR) and communicating CSR issues, models and strategies. Therefore, different sources such as Emerald, UoC Library database, JSTOR, URLs, SCOPUS, Corporate annual reports, books, journals, periodicals, internet, bitc (business in the community), WBCSD (World Business Council for Sustainable Development), CSR Forum of Asia and Europe, CSR Charters of different countries, \& environmental, constitutional, ethical, legal and governance frameworks and imperatives are utilized for constructing the domains of secondary data sources.

\subsection{Data Collection Instrument: Questionnaire and Focus Group}

The study has collected data by administering a questionnaire. The questionnaires consist of both structured and semi-structured questions. Exactly 15 questions have been divided into three sections such as CSR: Awareness Issues, CSR: Attitudes and Perceptions and CSR: Communication Channels and techniques. Likert's 5 point scale questions are used in a section to measure the social attitudes of business and non-business stakeholders. The survey has been administered through telephone, mail, email, facebook, Internet, and direct interviews with the respondents. The questionnaire was divided emphasizing on three broad areas such as CSR awareness issues, CSR perceptions and attitudes and CSR communication. One hundred questionnaires were sent to the target respondents and received 73; sixty of them are finally accepted as sample and thirteen questionnaires have been rejected as least useful due to incompleteness, showing low awareness on the research issue and ambiguity.

Moreover, a focus group study was administered through Skype video conferencing. The focus group was consists of ten participants ( a pilot sample) representing ten different professional groups in Bangladesh (i.e. a University teacher, a lawyer, an NGO representative, a General Physician, an Industrialist/ Entrepreneur, a Politician, a Chairman of Local Government, an MBA Student, a Journalist and a Manager of a corporation). Data had been collected in between the $1^{\text {st }}$ January, 2017 to $20^{\text {th }}$ February, 2018; Focus group video conference was organized on $17^{\text {th }}$ February, 2019. The focus group video conferences (with the 10 leading representative respondents) were held to investigate their opinions if there is any phenomenological change on the their earlier responses provided.

\subsection{Data Analysis Tools and Techniques}

Finally data has been analyzed using both prescriptive and descriptive statistical tools. Arithmetic tools like percentage, ratios etc. also used for the purpose of analyzing data and facts. Microsoft Office Excel (data analysis tool pack) is used to input, process, outputs and present the data.

\section{Major Findings and Discussions}

Contemporary empirical studies, reviewed literature and research indicate that CSR is still a subject of debate and dialects. CSR conceptual framework has not yet commonly agreed nor is its boundary shaped. This study has obtained some interesting findings based on primary data analysis. Some of these findings are consistent with some earlier researches but some findings don't agree coherently with the findings of those earlier studies. This section of the research exhibits some valuable empirical findings and results about CSR and CSR communication issues and strategies. The study shows that the respondents have been heard/ learned/ known about CSR for 9 years approximately; actual mean is 8.6 years (Source; respondents data analysis). Hence, the target respondents show high awareness and keen interest to the research topic and answered the questions very thoughtfully.

\subsection{CSR defined, Issues and Areas of CSR Identified by Respondents:}

Many of the respondents have defined the CSR from their own concept. Some definitions are seemed interesting and very consistent with definitions given by researchers, authors and academicians. For instances, according to a respondent ' $\mathrm{CSR}$ is a business philosophy that emphasizes on corporate house has to consider a long term vision 
centering the society as a whole'. While another respondent argues that 'CSR is not only involved to provide scholarship, celebrating international days, organizing blood donation programs or arranging tree plantation programs etc. but also involves ensuring a quality of work life within the organization for the employees, paying the workers on time at the beginning of the month, adjusting their basic pay with cost of living according to consumer price index (CPI), finally promoting compliances of work facilities'. A respondent viewed CSR as a commitment of 'giving back' to the society. Some of the respondents have viewed 'CSR as a commitment by business to society to behave ethically', and 'as the internal moral code of conduct of corporate bodies that ensures that they do not harm the society by their business activities, and if possible, give back to the society from which they benefit'. The focus group has identified a number of CSR issues corporate ethics and good governance first that will transform other issues such as environment, consumers, society and other stakeholders' interests. The group has identified some areas of CSR. The group argues that business houses are the social economic entities; society expects that they should behave as good corporate citizen, they should comply with legal, ethical and moral issues and business enterprises must carefully address the social and environmental issues. This view is consistent with Carroll's (1991) CSR Pyramid of economic, legal, ethical and philanthropic model.

\subsection{First Source of CSR Information}

The research was keen to understand what was the first source of CSR information of the respondents? Data analysis exhibits the following column diagram.

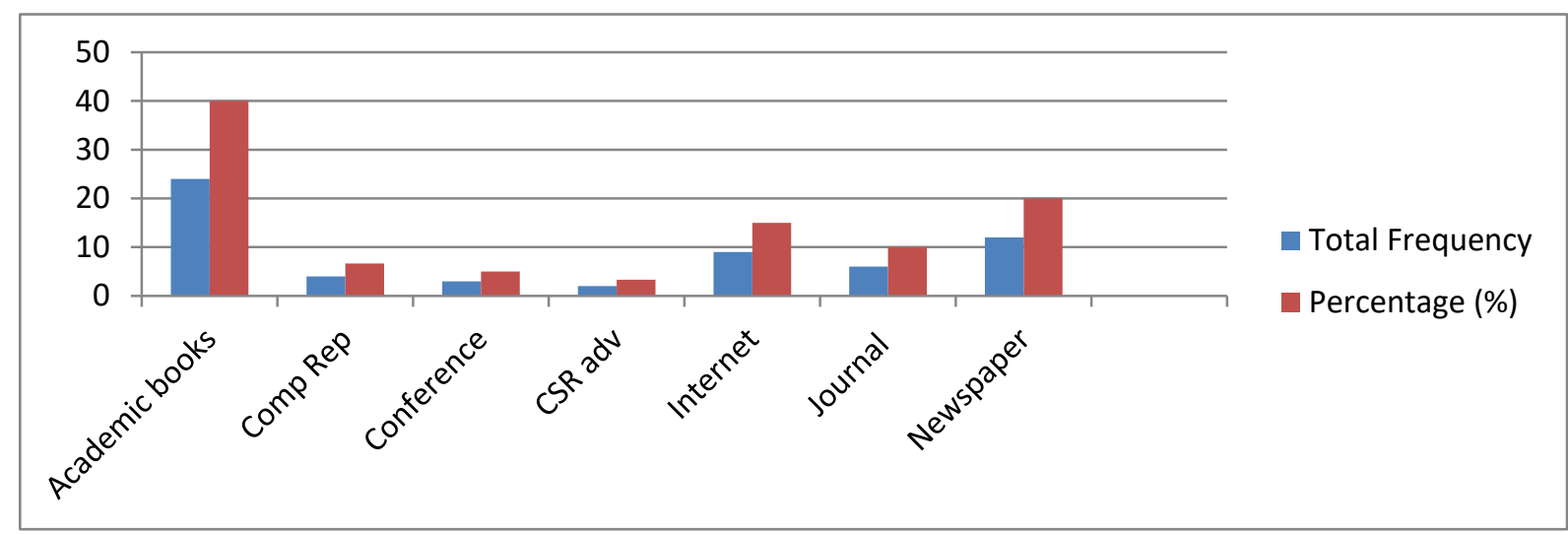

Exhibit 1. Respondent Data Analysis

The graph shows that $40 \%$ of the respondents have received CSR information from their academic books while newspaper (20\%) and internet (15\%) are the second and third sources of first CSR information.

\subsection{Is Your Company Socially Responsible?}

The respondents were asked directly whether his or her company (or organization, or institution s/he is involved) is socially responsible. The respondents' data analysis shows the following pie chart.

\begin{tabular}{|c|c|}
$\begin{array}{r}\text { my company is socially } \\
\text { Responsible }\end{array}$ \\
my company isn'tResponsible
\end{tabular}

Exhibit 2. Respondent Data Analysis

It's unexpected that $75 \%$ of the respondent straightly answers that his or her company is not socially responsible while only $25 \%$ of them countered by 'yes'. This result is fully consistent with respondents' perception and attitude, mean2.45 , towards the business's orientation to go beyond the profit orientation and making the world better place. But, this result show direct contradiction with 'the recent business trend' emphasized by Robins (2005).

\subsection{CSR Contributing Actions by Company: Respondents' Predilection}

The participants in the survey were asked to prefer CSR contributory actions (Q5 in Appendix A; Survey Questionnaire) from a given list of popular CSR actions. The responses is derived into following bar diagram. 


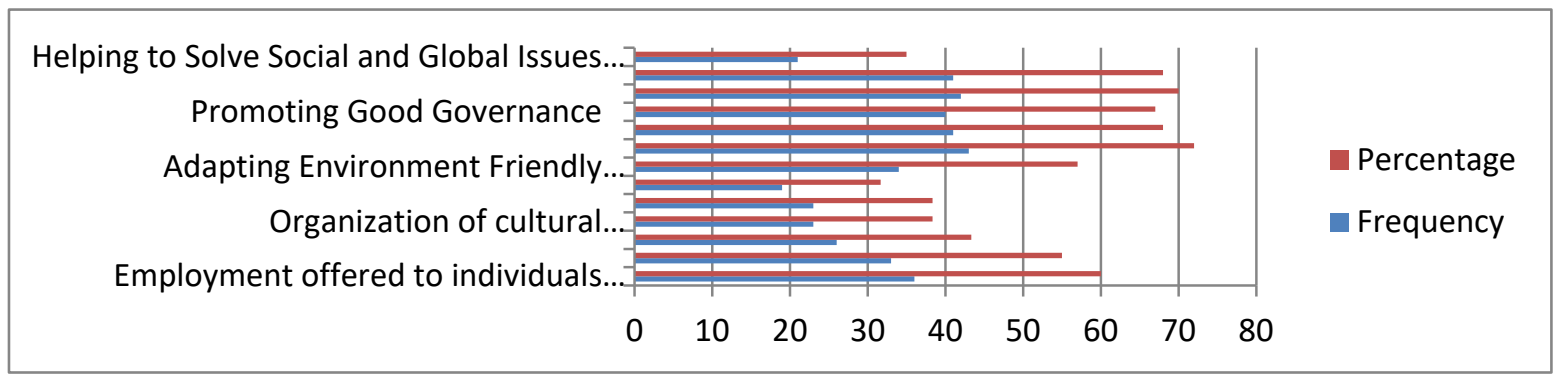

Exhibit 3. Respondent Data Analysis

Research indicates that companies today are observing various CSR actions and practices as commitments towards stakeholders, society and environment. The examined samples show that $72 \%$ of the participants emphasized on protecting carbon emission by the industries. The data analysis shows that 'the compliances of laws and regulations', 'promoting business ethics and transparency' and 'protecting consumer's rights' are chosen with high priority and given predilections by $70 \%, 68 \%$ and $68 \%$ of the respondents respectively. It's interesting that the fourth popular action is promoting good governance is selected by $67 \%$ of the respondents. The fifth choice is 'offering employment to socially vulnerable people $(60 \%)$ ' and 'adapting environment friendly production technology $(57 \%)$ ' is the sixth popular CSR action while supports to disadvantage people of the society $(55 \%)$ has gained seventh predilections by the respondents. The results indicate that people are expecting businesses to tailoring environmental issues and promoting business ethics, norms, transparency and good governance first, and, then to be involved in other popular actions like helping vulnerable and disadvantaged people, social charity and philanthropic activities etc. The finding is consistent with a research by Money and Hillenbrand (2005) in UK, which indicates that there is a clear message to businesses that it is important to companies to be responsible first to the employees and customers before tackling community projects.

\subsection{CSR Views, Issues and Role of CSR Communications: Some Significant Findings}

- The respondents are divided in answering all questions of the questionnaire except two structured questions i.e. Q-6 and Q-7 (Appendix A: CSR Questionnaire). The result shows a unanimous agreement (100\%) that companies should not only maximize production and profit and companies should have obligations and responsibility to the society. The following column diagram is depicting the findings.

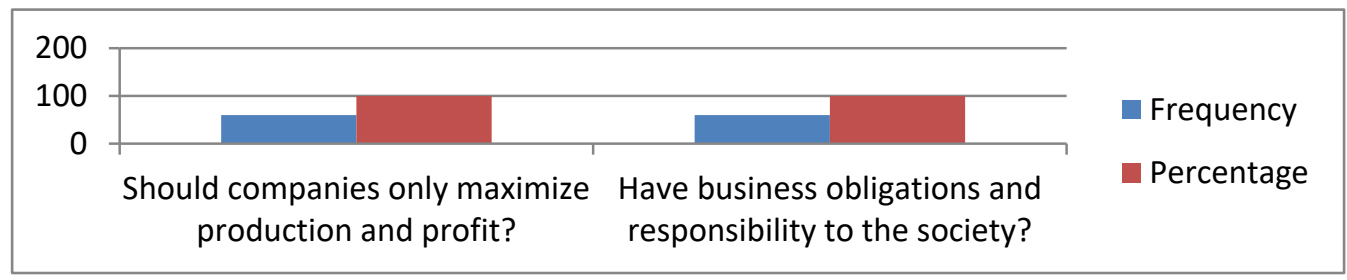

Exhibit 4. Respondent Data Analysis

This result is directly contradicted with the view of Levitt (1958), in his famous writing The Danger of Social Responsibility, that social responsibility is recognized as government's job only. Furthermore, the finding also clearly oppose to the views of Friedman (1970) that "the sole purpose of the corporation is to maximize the financial return to its owners" and his followers.

The respondents are asked to order profit and social responsibility. A good trade-off/ combination between profit and social responsibility is agreed by $70 \%$ responses while $15 \%$ reply settled evenly on both 'First Profit then CSR' and 'First CSR then Profit'. The result is demonstrated in the following column diagram.

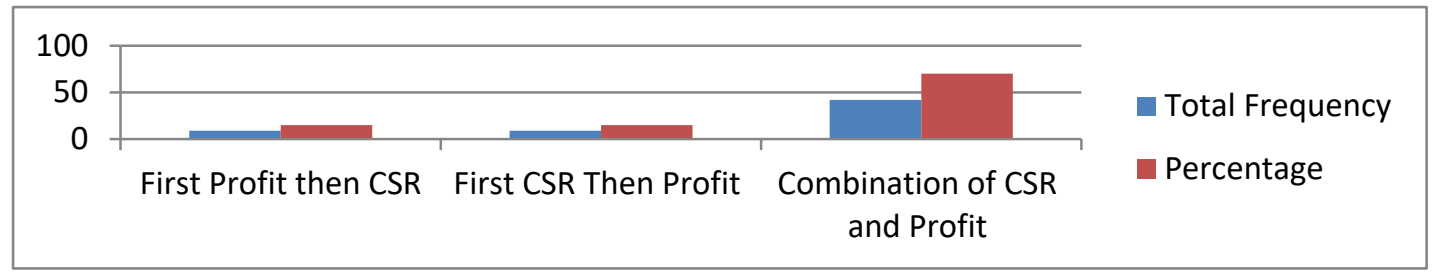

Exhibit 5. Respondent Data Analysis 
- The $80 \%$ of the respondents has positively replied that CSR enhances Customer's loyalty, brand image and company's reputation. Only $12 \%$ of the respondents disagreed it while very few $(8 \%)$ of them are abstained away from giving consent. This finding is consistent with the research results by Du et al (2007), Fombrun et al (2000), Lichtenstein et al (2004), Sen and Bhattacharya (2001), Sen et al 92006) and Turban and Greening (1997). The research effect of the result is also absolutely steady to the research findings by $\mathrm{Du}$, Bhattacharya, and Sen (2010) which reveal that CSR communication boosts customer's positive word-of-mouth, advocacy, and loyalty and brand image. The research outcome is portrayed below in the bar chart.

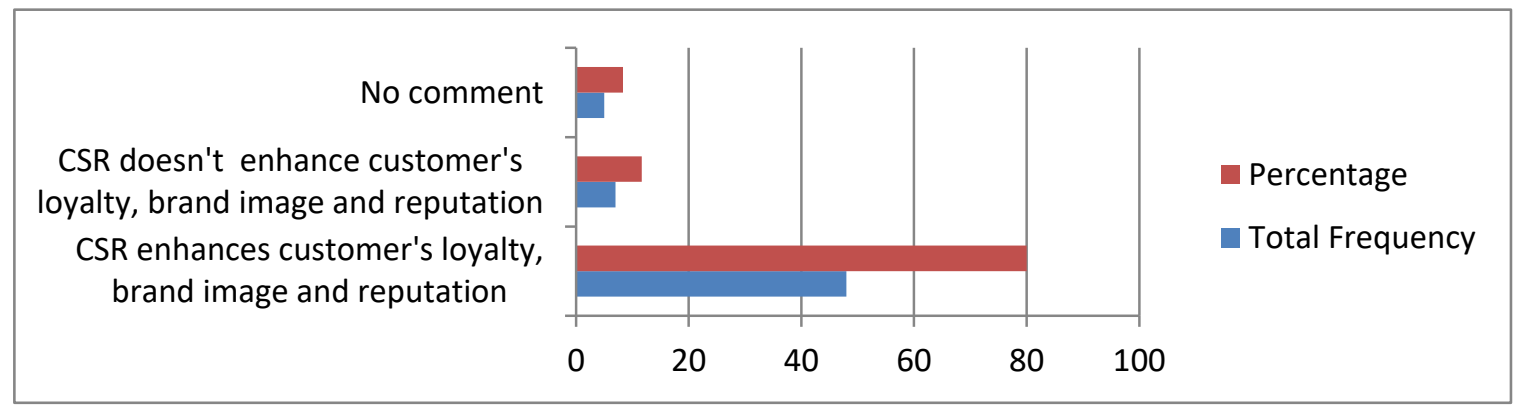

Exhibit 6. Respondent Data Analysis

- Are businesses carefully addressing social and environmental issues? Research result is illustrated below.

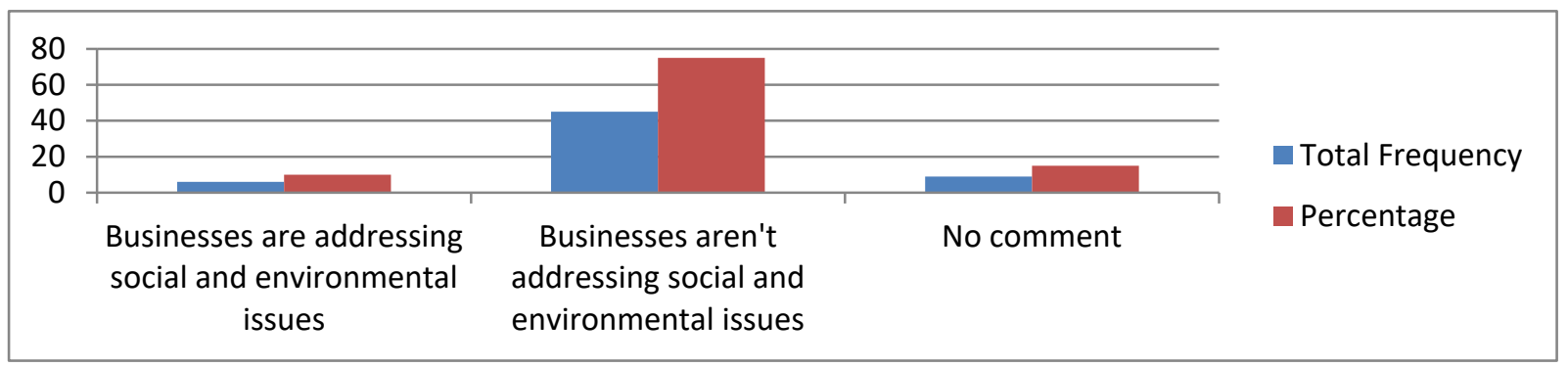

Exhibit 7. Respondent Data Analysis

According to the research result, $75 \%$ respondents has disapprovingly replied that businesses are not addressing social and ecological issues like poverty, inequality, illiteracy, food security, carbon footprint, deforestation, air and water pollution, climate change etc., while only $10 \%$ of them agreed on this issue. As research indicates, though sustainability reports produced by leading edge corporate houses reveal some examples of tailoring social and green issues but those are not sufficient initiative favoring this burning question of today. For instances, Walmart has come under attack for paying its associates (employees) low wages and pressuring them to work long hours without overtime pay (Hill and Jones, 2010: 121; Maich, 2004). Moreover, Virgin, Nike, Nestle, Dell, IBM, Jet Blue, Chevron, Occidental, Sony and most of the local and global companies are still fighting to settle the major issues like carbon footprint, air and water pollution, legal, ethical and good governance systems. For example, the fall of Enron in 2001 (Healy \&Palepu, 2003), Barclays had been fined $£ 290 \mathrm{~m}(\$ 450 \mathrm{~m}$ ) for trying to manipulate a key bank interest rate which influences the cost of loans and mortgage (BBC, 27 June 2012), A former Goldman Sachs board member has been found guilty of four criminal counts of insider trading by a federal court in New York, USA (BBC, 15 June 2012), and PUMA is accused for unethical wastes disposal, excessive overtime, high risk working conditions (China Labor Watch, 2008) etc. prove the corresponding relevancy of the research findings.

\subsection{Stakeholders Preferred Future CSR Practices}

Respondents were exposed to various CSR practices and asked (Q-13) to grade the popular ones on which they would desire additional information regarding CSR observed by the companies. The ranks are illustrated in the following bar diagram. Both high and low preferences are associated in the figure which has strengthened the way of ranking and evaluation. 


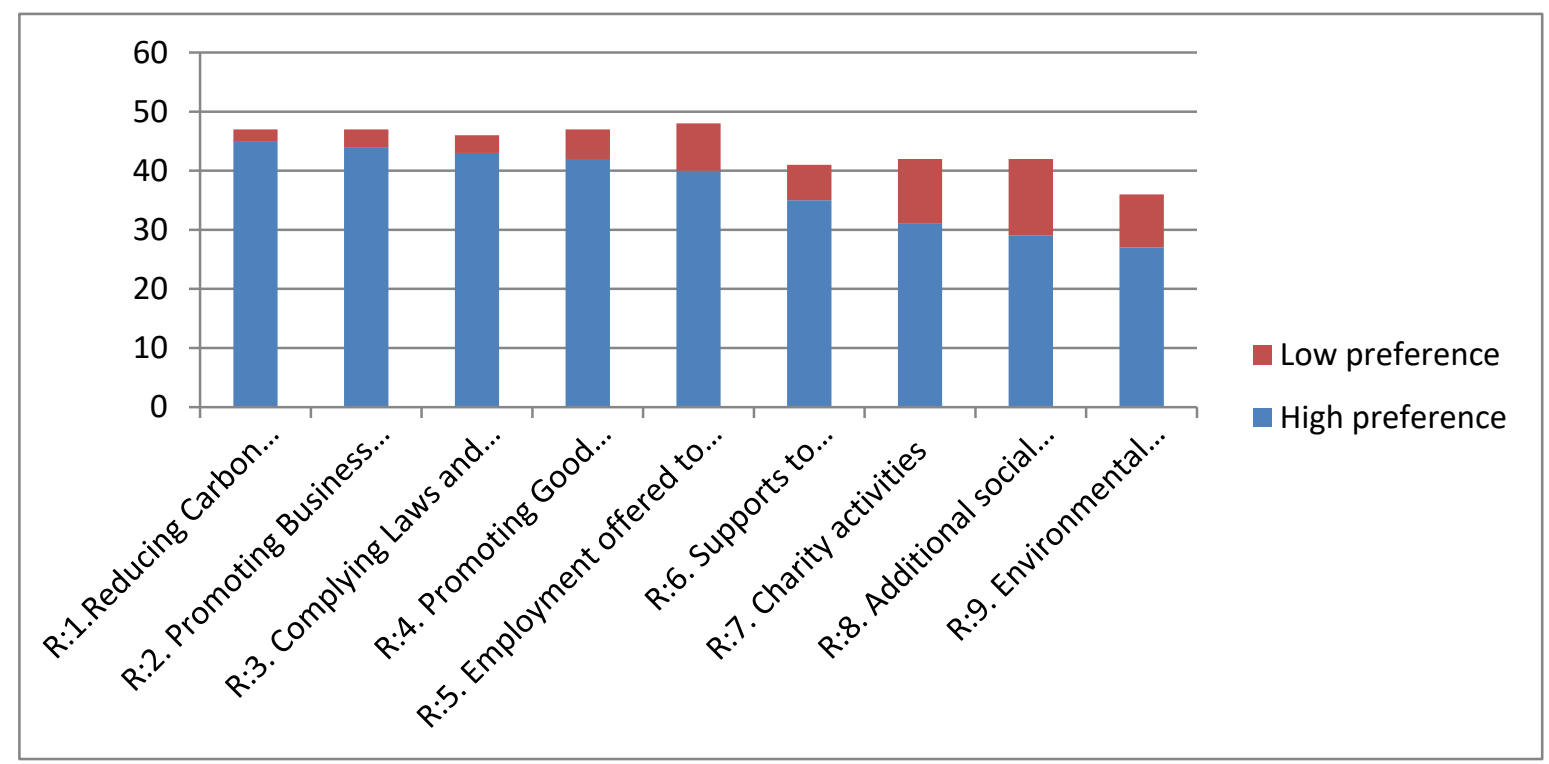

Exhibit 8. Respondent Data Analysis

The diagram shows that people love to know, firstly, what actions are taken by the enterprises to reduce carbon emission. It's interesting that very few participants have given lower preferences for it. Accordingly, Promoting Business Ethics and Transparency, Complying Laws and Regulations, Promoting Good Governance and Employment Offered to Individuals Belonging to Socially Vulnerable Groups are the $2^{\text {nd }}, 3^{\text {rd }}, 4^{\text {th }}$ and $5^{\text {th }}$ fondness graded by the respondents respectively. This result is consistent to the research outcomes in the earlier section of CSR Contributing Actions By Company: Respondents' Predilection.

\subsection{Publicizing CSR}

The business enterprises usually make public the CSR actions through different channels and media such as Company Web Sites, Annual Reports, Sustainability Reports, CSR Newsletter and Brochures etc. (Du, Bhattacharya, and Sen, 2010: 13). They have also argued on (as mentioned in the earlier section CSR Communications: Legitimacy, Channels and Strategies.) some other CSR disseminating channels like TV commercials, magazine or billboard advertisements, and product packaging to communicate CSR initiatives. Following their research this study has an endeavor to find out the most suitable bodies and medias for the business enterprises through which they can publicize CSR programs to their stakeholders. The analysis is presented in the following exhibition.

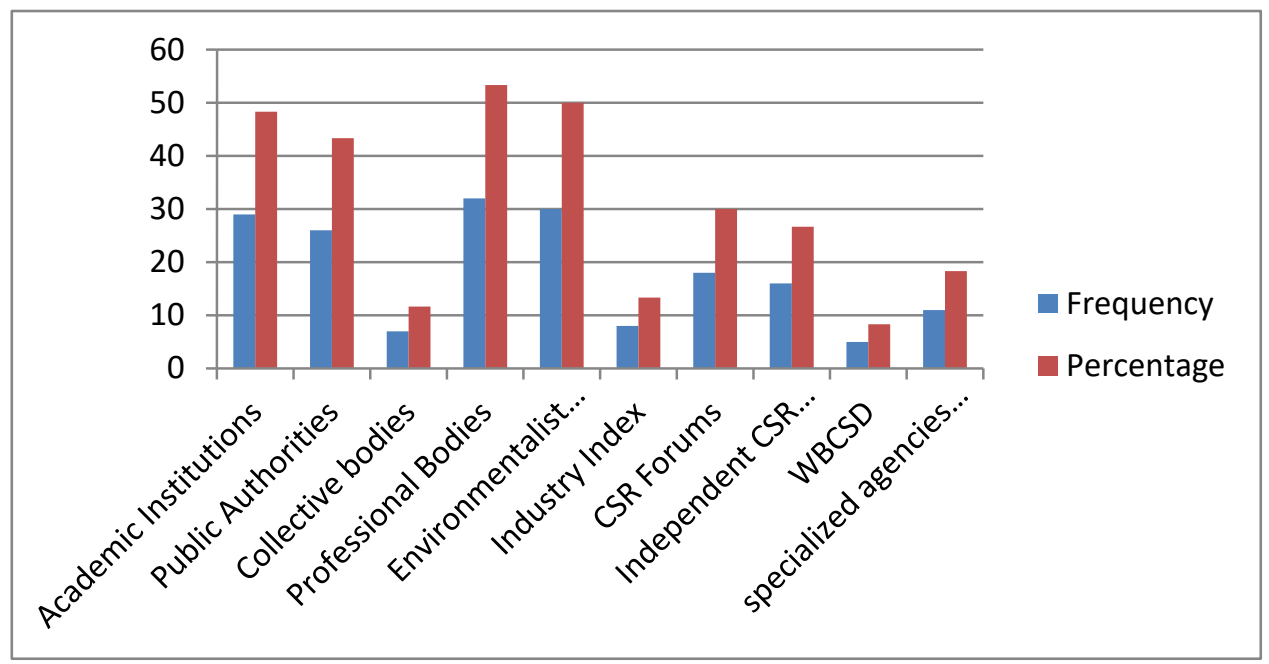

Exhibit 9. Respondent Data Analysis

The graph shows that professional bodies, environmentalist and consumerist groups and academic institutions are highly preferred bodies by the respondents for communicating CSR activities. Therefore, it can be inferred that firms 
can effectively communicate CSR actions through 'expert-third-parties' like social and political bodies, academic institutions or local government authorities etc. who are familiar with CSR issues. This research result conforms with the research by Morsing, et al. (2008) where third party association (Politicians, NGOs and Journalists) was emphasized for the purpose of disseminating CSR actions to the stakeholders.

\subsection{CSR and CSR Communications: Stakeholders' Perceptions and Attitudes Measured}

In an attempt to construct an overview of the fragmented area of research findings and addressing the relationship between CSR and stakeholders' perceptions and attitudes the study constructs Likert's-5-scale ( 1- Strongly Disagree, 2- disagree, 3- Neutral, 4- agree and 5- Strongly agree) and data is collected on ten recent research outcomes or phenomenon assuming variables 1,2,3,..10 (Appendix A: Data collection Instrument- Questionnaire). This section exhibits and discusses the results of data analysis so that importance of strategic fit between company and CSR causes are understood and CSR communication is managed effectively and efficiently. The summary statistics is presented below in Table-1.

Table 1. Stakeholders' Perceptions and Attitudes Measured

\begin{tabular}{llllllllllll}
\hline * Levels of respondents: CEO, ME, RA & Var. & Var. & Var. & Var. & Var. & Var. & Var. & Var. & Var. & Var. \\
and SPL & $\mathbf{1}$ & $\mathbf{2}$ & $\mathbf{3}$ & $\mathbf{4}$ & $\mathbf{5}$ & $\mathbf{6}$ & $\mathbf{7}$ & $\mathbf{8}$ & $\mathbf{9}$ & $\mathbf{1 0}$ \\
\hline Mean & 2.45 & 4.25 & 4.20 & 4.12 & 3.63 & 3.22 & 1.62 & 2.88 & 4.15 & 4.00 \\
Standard Error & 0.11 & 0.11 & 0.10 & 0.13 & 0.14 & 0.12 & 0.11 & 0.17 & 0.11 & 0.11 \\
Median & 2 & 4 & 4 & 4 & 4 & 3 & 1 & 3 & 4 & 4 \\
Mode & 2 & 5 & 4 & 5 & 4 & 4 & 1 & 3 & 4 & 4 \\
Standard Deviation & 0.87 & 0.82 & 0.75 & 1.01 & 1.10 & 0.96 & 0.88 & 1.35 & 0.82 & 0.84 \\
Sample Variance & 0.76 & 0.67 & 0.57 & 1.02 & 1.22 & 0.92 & 0.78 & 1.83 & 0.67 & 0.71 \\
Kurtosis & 0.45 & 2.75 & 6.07 & 0.01 & -1.26 & -1.19 & 1.41 & -1.09 & 2.14 & 2.84 \\
Skewness & 1.19 & -1.27 & -1.82 & -0.85 & -0.23 & 0.02 & 1.46 & -0.08 & -1.05 & -1.40 \\
Range & 4 & 4 & 4 & 4 & 3 & 3 & 3 & 4 & 4 & 4 \\
Minimum & 1 & 1 & 1 & 1 & 2 & 2 & 1 & 1 & 1 & 1 \\
Maximum & 5 & 5 & 5 & 5 & 5 & 5 & 4 & 5 & 5 & 5 \\
Sum & 147 & 255 & 252 & 247 & 218 & 193 & 97 & 173 & 249 & 240 \\
Count & 60 & 60 & 60 & 60 & 60 & 60 & 60 & 60 & 60 & 60 \\
\hline Sources Respon
\end{tabular}

Sources: Respondent Data Analysis (Appendix 1: Data Analysis Work-Sheet-1) *Levels: CEO: Chief Executive Officer, ME: Manager and Executive, RA-Researchers and Academicians, SPL: Social and Political Leaders. ** The analysis of each Variable is discussed below.

Var.1: The recent business trend emphasizes that firms are expected to go beyond their profit-oriented activities and boost the wellbeing of the community, making the world a better place.

Statistical summary table- 01 shows that the mean of this variable is $\mathrm{M}=2.45$ indicating the recent business tendency is not laying emphasis on social welfare as well as enterprises are more impinging on profit orientation. The cross tabulations of the scaled opinions is depicted in the following column chart

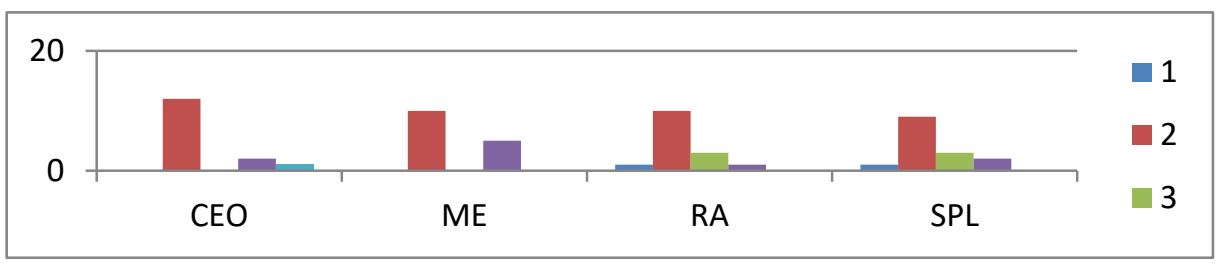

Exhibit 10. Respondent Data Analysis; (Appendix 1: Data Analysis Work-Sheet-1) 
The chart shows that total 41 respondents among 60 (12 CEOs, 10 Managers/ Executives-ME as well as Researchers/ Academicians-RA and 9 Social and Political Leaders-SPL) have showed disagreement on the issue. It's interesting that negative perception on the issue is higher among the CEOs, ME and RA than the Social and Political Leaders. The result is also cohesive with Exhibit-7 of the study but shows contrast with Robins' (2005) argument that firms are going beyond profit orientation and motivated by society driven action like welfare.

\section{Var.2: There is a high interdependent and interacted relationship in between society and business houses}

The interdependence between society and business is widely accepted and agreed phenomenon. Research indicates that a good number of authors, social scientists and academicians argued in favor of this fact. The research result also shows high compliance with it. The cross tabulation shows that 51 among 60 respondents agreed/ strongly agreed, Mean $=4.25$, on it while only 1 manager disagreed and others (only 8 ) remained away from giving consent on either side. This empirical outcome appreciably supports the famous argument by Davis and Frederick (1985) that business and society can't exist without each other. The cross tabulation diagram is portrayed below in the bar diagram.

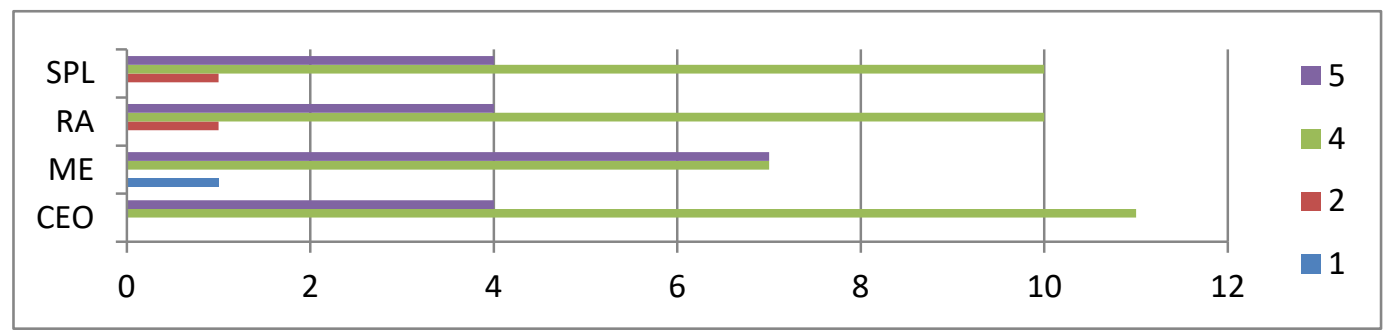

Exhibit 11. Respondent Data Analysis; (Appendix 1: Data Analysis Work-Sheet-1)

Var.3: Businesses are obliged to satisfy the needs of various stakeholders and to meet the expectation of various stakeholders; businesses have to undertake a series of management behavior onward.

Table 01 points out that the mean of the variable is 4.20 . The cross tabulation shows that 57 respondents agreed (19 agreed strongly) that business has obligation to meet the various needs and expectations of the stakeholders and management should accept the responsibilities towards it. The cross tabulation analysis is demonstrated below.

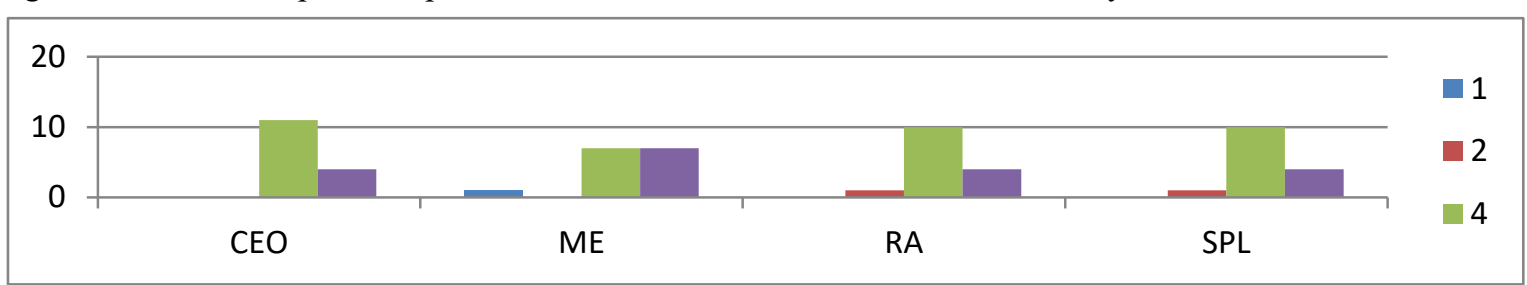

Exhibit 12. Respondent Data Analysis; (Appendix 1: Data Analysis Work-Sheet-1)

This finding reveals the high consistency with the researches by Clarkson (1995), Jamali and Mirshak (2007) and Castka, and Balzarova (2008) who argued on various social obligations of business, and reinforce stakeholder-company tie and build corporate image (Du et al., 2010), and helps business achieving long-term sustainability as a strategic driver of businesses (Baron, 2001; Werther and Chandler, 2006).

Var.4: Social Responsibility should involve the conduct of a business so that it is economically profitable, law abiding, ethical and socially supportive.

Today businesses are no more involved to only profit maximization or wealth maximization. The fall of Enron and other corporate scams all over the world has brought wider outlook towards business orientations. Table 01 shows that the mean of the variable is 4.12 which significantly supports the urgency of conducting business not only profitably but also firms should comply legal, ethical and social imperatives proficiently. The cross tabulation is demonstrated in the following diagram. 


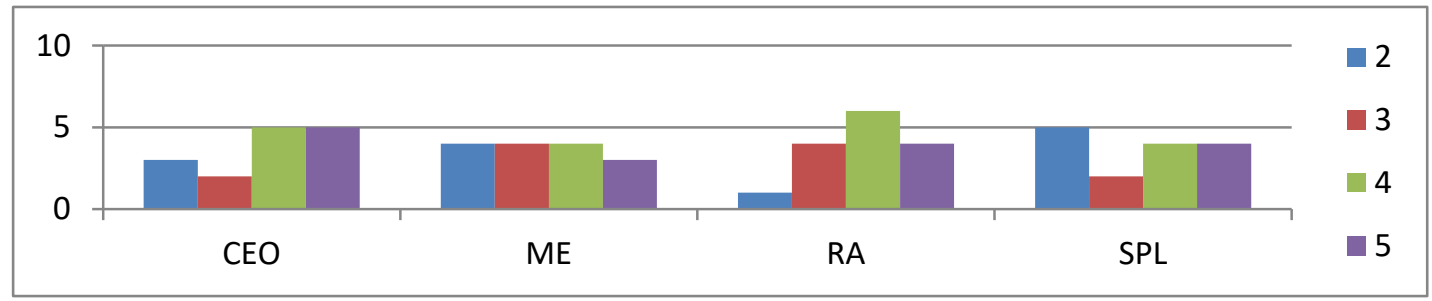

Exhibit 13. Respondent Data Analysis; (Appendix 1: Data Analysis Work-Sheet-1)

The analysis reveals that 53 respondents accepted/ strongly accepted the trade-off between profit and other concerns of business such as norms, ethics and social demandingness. Moreover, the result signifies the findings by Carroll (1983) and McWilliams and Siegel (2001) who argue that abiding by law is the foremost condition for businesses to behave ethically and socially, furthermore, research finding by Lindblom (1994) who argued that there's a potential threat for business if societal goals and business goals are congruent.

Var.5: By dint of CSR activities, companies can not merely yield favorable attitudes and behaviors from stakeholders, but also reinforce stakeholder-company bonding and construct corporate image

The cross tabulation shows that 58\% (35 among 60 , Mean $=3.63$ ) of the respondents supported or strongly supported toward this CSR value. The result is depicted below in the column diagram.

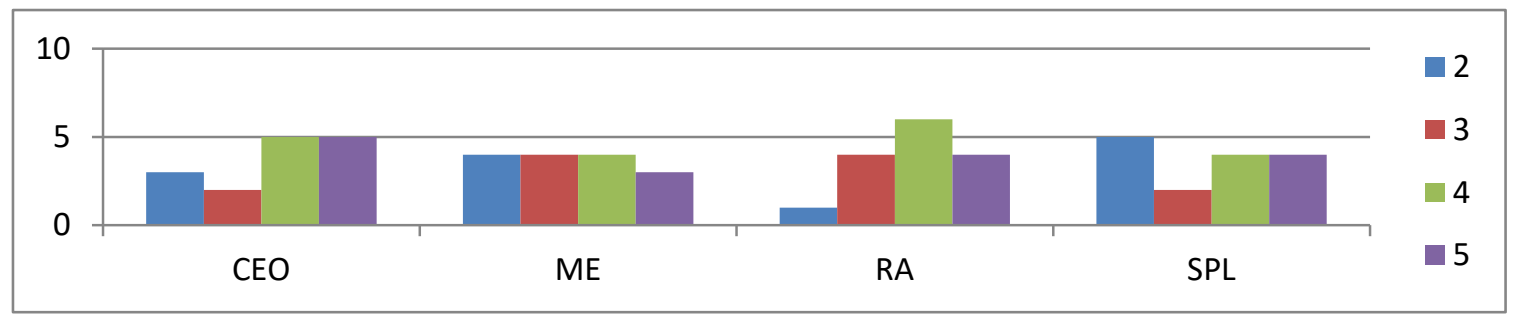

Exhibit 14. Respondent Data Analysis; (Appendix 1: Data Analysis Work-Sheet-1)

The finding is logically relevant to the research results obtained by Du et al. (2010), Du et al. (2007), Fombrun et al. (2000), Lichtenstein et al. (2004), Sen and Bhattacharya, (2001), Sen et al. (2006) whose findings are pointing out various benefits harvested by business in spite of CSR activities. The result is also complementary to the researches by Birch (2003), Rowe (2006), and Mason et al. (2007) who recognize that businesses are social citizen / enterprises which should have responsibilities to the society.

Var.6: Consumers love CSR practicing companies on the other hand they punish firms that are perceived to be insincere in their social involvement

Statistical summary (Table 01) shows that the mean of the variable is 3.22 and characterizes the participants' attitudes are neutral. The following diagram depicts the result of cross tabulation.

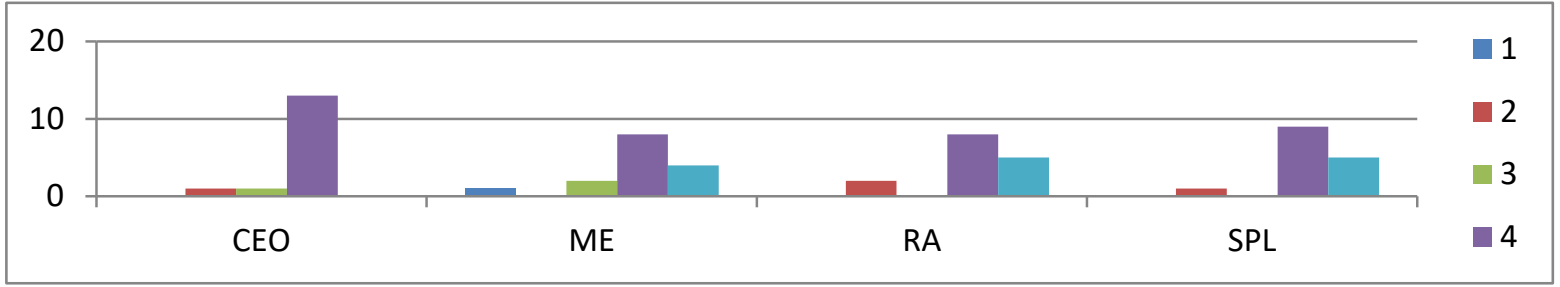

Exhibit 15. Respondent Data Analysis; (Appendix 1: Data Analysis Work-Sheet-1)

The diagram represents that though $45 \%$ respondents agreed with the statement very few (about $7 \%$ ) of them agreed strongly, on the other hand, $30 \%$ of the respondents disagreed with the statement. It's noticeable that higher number of researchers/ academicians perceived the argument disapprovingly vice versa to CEO, ME and SPL. The finding neither 
approves nor rejects the research results that 'consumer loves CSR practicing companies and punish who don't, and CSR positively impacts the employee engagement and involvement'- argued by Sen and Bhattacharya (2001) and Brammer et al. (2007) respectively.

Var.7: Doing Social welfare and solving social problems are not the subject matter of the business enterprises because the government is responsible for that.

The lowest mean $(\mathrm{M}=1.62)$ of the variable evidently articulate that the phenomenon is strongly denied by the respondents. The cross tabulation is illustrated below.

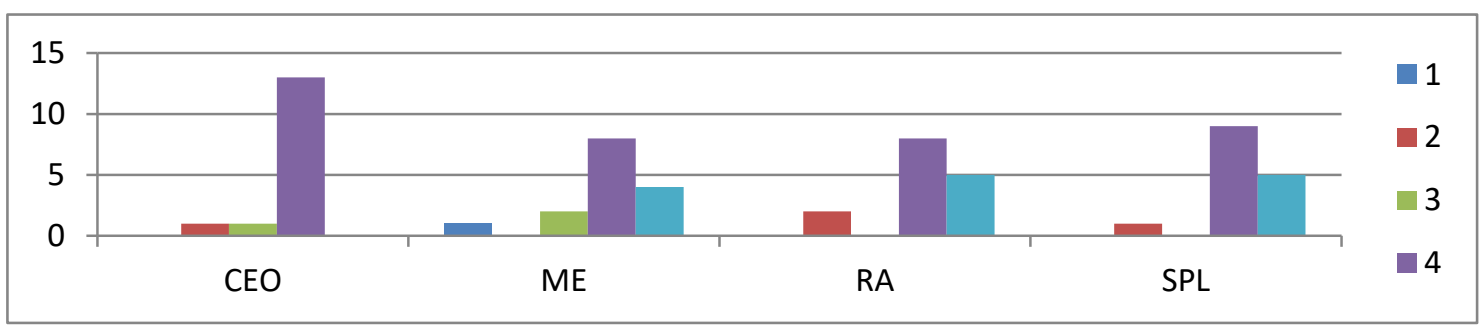

Exhibit 15. Respondent Data Analysis; (Appendix 1: Data Analysis Work-Sheet-1)

The chart shows that about $87 \%$ perceptions and attitudes of the respondents oppose the statement while $58 \%$ of them strongly disagreed. It's conspicuous that no CEO has agreed with this critical view while only one ME choruses with merely $6 \%$ positively perceptible group. Thus, the critical views of Levitt (1958) and Friedman (1970) are contrasted by the research findings.

Var.8: CSR involvement enhances the corporate houses' power, as a result, those enterprises dominates the society politically and economically and thus exploit the society.

Statistical summary report shows the mean result is 2.88 which a neutrally perceptible situation. The cross tabulation analysis is depicted below

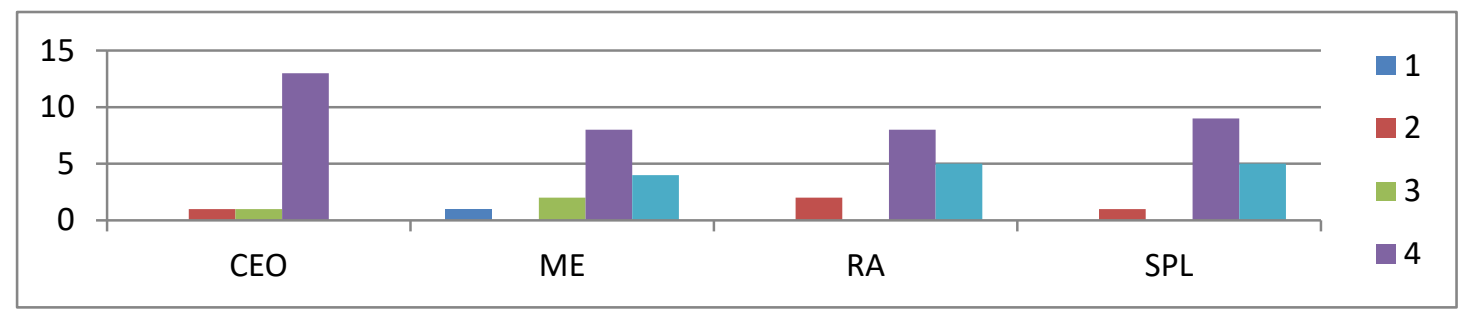

Exhibit 16. Respondent Data Analysis; (Appendix 1: Data Analysis Work-Sheet-1)

Cross tabulation outcomes are displaying an amazing perceptional paradox on the issue. The respondents are evenly divided into three attitudinal groups; 'disagreed', 'neutral' and 'agreed'. As a result, the issue remained undecided but critics like M. Friedman, T. Levitt and their followers are again in the focal point. However, $25 \%$ of the respondents have strongly disagreed on the variable while only $8 \%$ of them agreed. Hence the critiques are neither discarded nor applauded.

Var.9: CSR strategic implications are enormous for example; social prosperity corresponds to long-term business profit and growth, higher purchasing capacity to higher market shares of business and higher social sustainability to long-term business sustainability etc

Statistical summary table confirms that the mean of the variable is 4.15 which demonstrates the positive perception about CSR strategic implications. Research indicates various (positive) strategic implications of CSR that are cohesive to the cited examples in this statement. Research findings are presented below in a column diagram. 


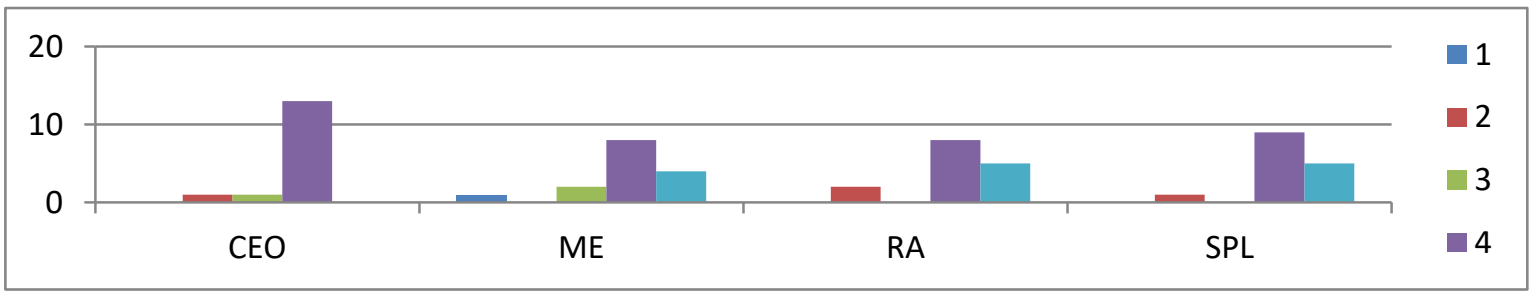

Exhibit 17. Respondent Data Analysis; (Appendix 1: Data Analysis Work-Sheet-1)

The figure indicates that CSR strategic outcomes are favorably agreed by $82 \%$ of the participants which is contradicted by only $2 \%$. Real world scenario also relevantly coincide the research findings. The case studies of leading-edge companies like Walmart, Nestle, Jet Blues, Apple, Dell, Facebook etc. have shifted paradigm of CSR strategic implications like global image, competitive advantage, stewardship of technology, greening supply chain and sustainable growth are prominent.

Var.10: Companies today are becoming more and more aware of Communicating CSR as a way to make positive imprint among the stakeholders and exchange of CSR efforts to them successfully.

The finding indicates that companies are increasingly motivated to attract positive impression of the stakeholders through the exchange of CSR efforts and activities. Sones (2007) studied six US Pharmaceutical companies and found that vision and mission statements of those enterprises were conveying CSR roles and efforts to the stakeholders significantly. The analysis of current research result is presented below.

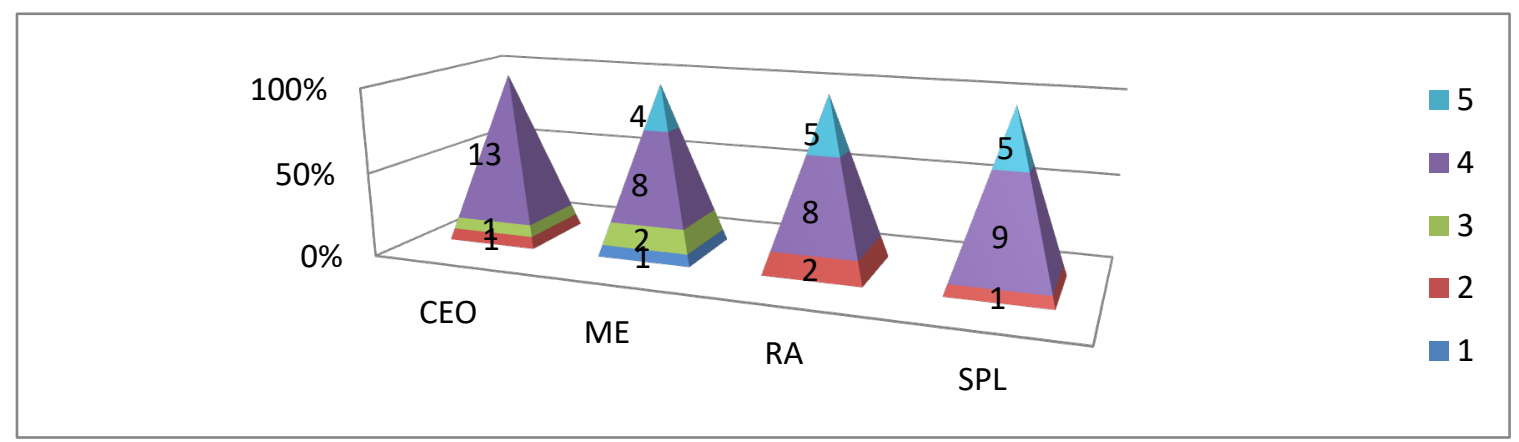

Exhibit 18. Respondent Data Analysis; (Appendix 1: Data Analysis Work-Sheet-1)

Summary statistics in table 01 reveals that the mean of the variable is 4.00 and Exhibit- 18 shows $87 \%$ responses convicted the statement favorably while only $8 \%$ perceived against the phenomenon. Hence, it is agreed that companies are becoming increasingly aware of communicating CSR with the stakeholders. However, Esrock and Leichty (1998) studied a sample of 100 Fortune 500 companies and found that about $90 \%$ companies have websites which are underutilized and not harvesting potential benefits of using websites as a communicating medium to communicate CSR activities. Adams and Frost (2006) study also revealed some limitations of using web-pages by 100 companies in Australia, Germany, and in the UK, and argued that most of these companies are poorly utilizing Web as CSR communicating strategy.

\section{Conclusion and Policy Recommendation}

The study explored two research questions and produced several empirical findings. Moreover, each finding is investigated through cross references with the existing studies and then research inferences are drawn for every particular outcome. Some of the findings are coherently and comprehensively consistent with the earlier research views but others don't. The variables measured as social perceptions and attitudes are selected from the findings of early popular researches and examined the significant value by the current study. Most of these phenomenons are convicted empirically, and result shows either consistency, or partially supported or fully contradicted. But a largely popular variable (Var.6, Exhibit-15) "Consumers love CSR practicing companies on the other hand they punish firms that are perceived to be insincere in their social involvement (Sen and Bhattacharya, 2001)" is still undecided. The respondents have given evenly distributed consents (33.33\% or 20 in each group) as disagreed, neutral and agreed. As 
a result, critiques like Levitt (1958), Friedman (1970) and their followers are neither discareded nor applauded, though their views are rejected by the most of the existing CSR researchers, are again in central attention.

However, with the globalization of economic development and evolution of corporate management methods, the meanings of corporate social responsibility (CSR) have dramatically changed in now-a-days. This change has positively led the government, businesses, and the society to have deeper understanding of CSR (Hsieh \& Chan, 2012). More and more businesses have become aware that they cannot simply fulfill their social responsibilities for stockholders in pursuit of core competitiveness. While maximizing their economic profits, they have to make efforts in other aspects of CSR, such as environmental protection, consumer benefits, and labor rights (Choi \& Nakano, 2008; Lai \& Hsu, 2012). But this study discovered some alarming findings such as $75 \%$ respondents have straightly mentioned that businesses are not carefully addressing the social and environmental issues like air and water pollution, carbon emissions, poverty, illiteracy etc. (Exhibit - 7), and an analysis of recent business trend (Mean $=2.45$ ) suggests that very few companies are going beyond the profit orientation and contribute to boost the social wellbeing (Statistical Summary Table 01 and Exhibit - 10). The respondents' predilections shows that popular CSR practices should cover actions like reducing carbon emission, promoting business ethics, complying legal and social imperatives (Exhibit 08).

Research indicates that companies are increasingly encouraged to communicate CSR actions and efforts to the stakeholders of the business. Companies are using various channels, techniques and strategies to communicate CSR initiatives to the stakeholders. This research results show that independent professional bodies, social and consumer's group and academic institutions are highly trusted channels to disseminate CSR issues (Exhibit 09). This finding is consistently arguing with the findings by Morsing, et al. (2008) that argues on $3^{\text {rd }}$ parties association (journalists, NGOs and Politicians) for the purpose of CSR communications. Moreover, the findings reveal that useful media of CSR communication are academic books i.e. companies are referred as examples or case study, internet and newspaper (Exhibit - 01). This research outcome contrasts to the most of the researches which argue on corporate social reporting, sustainable reports, CSR newsletter or brochures as CSR communicating tools.

The empirical anecdotes of the study and reviewed theoretical paradigm, therefore, significantly explored the research questions in order to achieve the research objectives that broaden aims of the study. The research findings will help the companies to understand CSR Issues, Roles, Approaches and Strategies. Moreover, by estimating interdependence between society and business the firms can shape their CSR actions and efforts reflecting social obligations, responsiveness and responsibility. Furthermore, this study will help the companies finding the ways to communicate CSR initiatives to the stakeholders to optimize the benefits of Corporate Social Responsibilities by crafting new and innovative CSR strategies.

\subsection{Limitations, significance and Future Research}

This research is constrained by some limiting factors such as limited sample size, unavoidable systematic error e.g. because of random sampling etc. Research fund was not granted neither by university nor by any sponsoring organizations and fund for the research was managed by the researcher. A granted fund would certainly make this research endeavor more worthy. However, still the research is esteemed very useful, significant and valuable to the future students, researchers and business organizations as a source of meaningful information, facts and data. It is expected that the original value of this research is enriched by a number of significant findings regarding CSR and CSR communication. These outcomes are derived from empirical analysis and CSR policy makers of both public and private organizations and practitioners might benefit by sharing and utilizing the research outcomes. Still there is large number of future research issues unexplored. Future researchers can investigate the issues like i) CSR communication can be lensed into diversed cultural contexts e.g. oriental (east) vs. occidental (west). ii) Motives of CSR and intentions of CSR communication are often diversed and should be justified from ethical and philosophical perspectives.

\section{References}

Adams, C. A., \& Frost, G. R. (2006). Accessibility and functionality of the corporate website: Implications for sustainability reporting.Business Strategy and the Environment, 154, 275-287. https://doi.org/10.1002/bse.531

Advertising Age. (2010). Ten Companies with Social Responsibility at the Core(April 19, p. 88)

Amaladoss, M. X., \& Manohar, H.L. (2011).Communicating Corporate Social Responsibility - A Case of CSR Communication in Emerging Economies.Corporate Social Responsibility and Environmental Management, 20 , 65-80. https://doi.org/10.1002/csr.287 
Anderson, J. W. (1986). Social Responsibility and the Coporation, Business Horizons(July- August, pp. 22-27, As quoted in Griffin, Ricky W.1997.,Management 5th ed. P.110 New Delhi, A.I.T.B.S. Publishers \& Distribution). https://doi.org/10.1016/0007-6813(86)90019-4

Arvidsson, S. (2009).Non-financial information and the annual report(working paper, Department of Business Administration, Lund University, Lund Associated Press, 2014, Februabry 10).

Aupperle, K. E., Carroll, A. B., \&Hartfield, J. D. (1985).An empirical examination of the relationship between corporate social responsibility and profitability. Academy of Management Journal, 28, 446-463. https://doi.org/10.2307/256210

Basu, K., \& Palazzo, G. (2008). Corporate Social Responsibility: A Process Model of Sensemaking.Academy of Management Review, 33(1), 122-136. https://doi.org/10.5465/amr.2008.27745504

Berle, A. A. Jr., \& Gardiner, C. (1932). The Modern Corporations and Private Property, New York, Commerce Clearing House, Inc.( As quoted in Wayne, G. Broehl, Jr. 1966, "Insights Into Business and Society" Harvard Business Review- Philosophy of Business Part II, (Number 66303), Reprinted in 1970, p.14-16)

Bhattacharya, C. B., \& Sen, S. (2001). Does doing good always lead to doing better? Consumer reactions to corporate social responsibility.Journal of Marketing Research, 28, 225-243. https://doi.org/10.1509/jmkr.38.2.225.18838

Bhattacharya, C. B., \& Sen, S. (2004). When, why, and how consumers respond to social initiatives.California Management Review, 47(1), 9-24. https://doi.org/10.2307/41166284

Binkley, C. (2010). Charity Gives Shoe Brand Extra Shine.Wall Street Journal, April 1, p. D7

Birch, D. (2003). Corporate social responsibility: Some key theoretical issues and concepts for new ways of doing business.Journal of New Business Ideas and Trends, 1, 1-19.

Bowie, N. E. (1999). Business ethics: A Kantian perspective. Oxford: Blackwell.

Brammer, S., \& Millington, A. I. (2004). The development of corporate charitable contributions in the UK: a stakeholder analysis. Journal of Management Studies, 41(8), 1411-38. https://doi.org/10.1111/j.1467-6486.2004.00480.x

Brammer, S., Millington, A., \& Rayton, B. (2007). The contribution of corporate social responsibility to organisational commitment. International Journal of Human Resource Management, 18(10), 1701-19. https://doi.org/10.1080/09585190701570866

Brown, K. (2001). Corporate Social Responsibility: Perceptions of Indian Business.In Mehra, M. (Ed.), retrieved from www.csmworld.org/public/fdf/social response.pdf, access on 02 February, 2014

Brown, N., \& Deegan, C. (1998). The public disclosure of environmental performance information-A dual test of media agency setting theory and legitimacy theory. Accounting and Business Research, 29(1), 21-42. https://doi.org/10.1080/00014788.1998.9729564

Brummer, J. J. (1991). Corporate responsibility and legitimacy: An interdisciplinary analysis. New York: Greenwood Press. Canham, B. (1994, October 8). P. 1.

Brunton, M., Eweje, G., \&Taskin, N. (2017). Communicating Corporate Social Responsibility to Internal Stakeholders: Walking the Walk or Just Talking the Talk? Business Strategy and the Environment. https://doi.org/10.1002/bse.1889

Carroll, A. B. (1983). Corporate social responsibility: Will industry respond to cut-backs in social program funding? Vital Speeches of the Day, 49, 604-60.8

Carroll, A. B. (1998). The four faces of corporate citizenship. Business and Society Review, 100/101, 1-7. https://doi.org/10.1111/0045-3609.00008

Carroll, A. (1999). Corporate social responsibility. Business and Society, 38(3), 268-295. https://doi.org/10.1177/000765039903800303

Carroll, A. B. (1989). Business and Society, Ethics and Stakeholder Management. Cincinnati, OH: South- Western College Publishing.

Castka, P., \& Balzarova, M. A. (2008). Social responsibility standardization: Guidance or reinforcement through certification? Human systems management, 27(3), 231-242. https://doi.org/10.3233/HSM-2008-0681 
China Labor Watch (CLW). (2008). LW's initial report, “PUMA Supplier's unchanged dreadful conditions “ based on Taiway, an exclusive supplier to PUMA for years.Retrieved from http://chinalaborwatch.org/pro/proshow-124.html ( accessed on 12.01.2014)

Cho, C. H. (2009). Legitimation strategies used in response to environmental disaster: A French case study of Total SA's Erika and AZF incidents.The European Accounting Review, 18(1), 33-62. https://doi.org/10.1080/09638180802579616

Cho, M., Furey, L. D., \& Mohr, T. (2017). Communicating corporate social responsibility on social media: Strategies, stakeholders, and public engagement on corporate facebook. Business and Professional Communication Quarterly. https://doi.org/10.1177/2329490616663708

Cifrino, P. (1956). The Mainspring of Business Leadership, Harvard Business Review, September-October, No. 56505, Harvard College, USA, as Reprinted in Business Harvard Review, Philosophy of Business(Part I, March-April, USA, 1964,pp. 109-116).

Corporate Responsibility Summary Report. (2013). Dell: The power to do more, Retrieved 6th February, 2014, from http://www.csrwire.com/reports/1317-Dell-FY13-Corporate-Responsibility-Summary-Report

Craig Smith, C. (1994). The New Corporate Philanthropy.Harvard Business Review, 105-107.

Davis, K., \& Blomstrom, R. L. (1975). Business, Society and Environment (pp. 67-68). New York: McGraw Hill Book Company.

Davis, K., \& Frederick, W. C. (1985). Business and Society. McGraw Hill, Singapore.

Dawkins, J., \& Lewis, S. (2003). CSR in Stakeholders Expectations: And Their Implication for Company Strategy. Journal of Business Ethics, 44(2-3), 185-193. https://doi.org/10.1023/A:1023399732720

Dawkins, J. (2004). Corporate responsibility: The communication challenge. Journal of Communication Management, 92, 108-119. https://doi.org/10.1108/13632540510621362

Deegan, C. (2002). Introduction: The legitimizing effects of social and environmental disclosures-A theoretical foundation. Accounting, Auditing \& Accountability Journal, 15(3), 282-311. https://doi.org/10.1108/09513570210435852

Dincer, B. (2011). Do the shareholders really care about corporate social responsibility? International Journal of Business and Social Science, 2(10), 71-6.

Donaldson, T., \& Preston, L. E. (1995). Stakeholder Theory and the Corporation: Concepts, Evidence and Implication.Academy of Management Review, 20(1), 65-91. https://doi.org/10.5465/amr.1995.9503271992

Druker, P. F. (1948). The New Meaning of Corporate Social Responsibility. California Management Review, winter, 26(2), 57-58.

Drumwright, M. E. (1996). Company advertising with a social dimension: The role of noneconomic criteria.Journal of Marketing, 60, 71-87. https://doi.org/10.1177/002224299606000407

Du, S., Bhattacharya, C. B., \& Sen, S. (2007). Reaping relationship rewards from corporate social responsibility: the role of competitive positioning. International Journal of Research in Marketing, 24, 224-241. https://doi.org/10.1016/j.ijresmar.2007.01.001

Du, S., Bhattacharya, C. B., \& Sen, S. (2009). Strengthening consumer relationships through corporate social responsibility( Working paper, Simmons College School of Management).

Du, S., Bhattacharya, C. B., \& Sen, S. (2010). Maximizing business returns to corporate social responsibility (CSR): the role of CSR communication. International Journal of Management Reviews, 12(1), 8-19. https://doi.org/10.1111/j.1468-2370.2009.00276.x

Elsbach, K. D. (2003). Organizational perception management.Research in Organizational Behavior, 25, 297-332. https://doi.org/10.1016/S0191-3085(03)25007-3

Falck, O., \& Heblich, S. (2007). Corporate Social Responsibility: Doing Well by Doing Good.Business Horizons 50(3), 247-254. https://doi.org/10.1016/j.bushor.2006.12.002

Freeman, R. E. (1997). A Stakeholder theory of the modern corporation.In Beauchamp T.L. and Bowie, N.E., (Eds.), Ethical Theory and Business. Prentice-Hall, Upper Saddle River, NJ. 
Freeman, R. E., Harrison, J., Wicks, A., Parmar, B., \& De Colle, S. (2010). Stakeholder Theory: The State of the Art. Cambridge: Cambridge University Press. https://doi.org/10.1017/CBO9780511815768

Friedman, M. (1962).Capitalism and Freedom, Chicago (p.133).The University of Chicago Press.

Friedman, M. (1970). The Social Responsibility of Business is to Increase its Profits.The New York Times, September $30,264-265$.

Ferreira, A. I., \& Ribeiro, I. (2017). Are you willing to pay the price? The impact of corporate social (ir)responsibility on consumer behavior towards national and foreign brands. Journal of Consumer Behaviour. https://doi.org/10.1002/cb.1603

Gainer, B. (2010). Corporate social responsibility. In Taylor, R. (Ed.), Third Sector Research (pp. 187-200). Springer, New York, NY. https://doi.org/10.1007/978-1-4419-5707-8_14

Gardberg, N. A., \&Fombrun, C. J. (2006). Corporate citizenship: creating intangible assets across institutional environments. Academy of Management Review, 31(2), 329-346. https://doi.org/10.5465/amr.2006.20208684

General Electric (GE). (2009). GE launches 'Healthymagination'; will commit \$6 billion to enable better health focusing on cost, access and quality. Retrieved from http://www. genewscenter.com

Golob, U., \& Bartlett, J. L. (2007).Communicating about corporate social responsibility: A comparative study of CSR reporting in Australia and Slovenia. Public Relations Review, 33(1), 1-9. https://doi.org/10.1016/j.pubrev.2006.11.001

Gossling, T., \& Vocht, C. (2007). Social role conceptions and CSR policy success.Journal of Business Ethics, 74(4), 363-372. https://doi.org/10.1007/s10551-007-9512-3

Greening, D., \& Turban, D. (2000). Corporate social performance as a competitive advantage in attracting a quality workforce. Business and Society, 3, 254-80. https://doi.org/10.1177/000765030003900302

Harrison, J. S., \& St. John, C. H. (1996). Managing and partnering with external stakeholders.Academy of Management Executive, 10, 46-60. https://doi.org/10.5465/ame.1996.9606161554

Harvey, G., Hodder, A., \& Brammer, S. (2017). Trade union participation in CSR deliberation: an evaluation. Industrial Relations Journal, 48(1), 42-55. https://doi.org/10.1111/irj.12167

Holme, R., \& Watts, P. (2000).Corporate social responsibility: making good business sense. World Business Council for Sustainable Development, Geneva, Switzerland.

Husted, B. W., \& Salazar, D. J. (2006). Taking Friedman seriously: maximizing profits and social performance. Journal of Management Studies, 43(1), 75-91. https://doi.org/10.1111/j.1467-6486.2006.00583.x

Ihlen, O., Bartlett, J., \& May, S. (2011). Corporate social responsibility and communication. In O. Ihlen, J. Bartlett, \& S. May (Eds.), the handbook of communication and corporate social responsibility (pp. 3-22), Chichester: Wiley-Blackwell. https://doi.org/10.1002/9781118083246.ch1

Jamali, D., \& Mirshak, R. (2007). Corporate social responsibility (CSR): Theory and practice in a developing country context. Journal of Business Ethics, 72(3), 243-262. https://doi.org/10.1007/s10551-006-9168-4

Jenkins, R. (2005). Globalization, corporate social responsibility and poverty. International Affairs, 81, 525-540. https://doi.org/10.1111/j.1468-2346.2005.00467.x

Jensen, M. C. (2001). Value Maximization, Stakeholder Theory, and the Corporate Objective Function. Journal of Applied Corporate Finance, 14(3), 8-21. https://doi.org/10.1111/j.1745-6622.2001.tb00434.x

Jones, T. M. (1980). Corporate Social Responsibility Revisited, Redefined. California Management Review, Spring, 22, 65. https://doi.org/10.2307/41164877

Jones, P., Comfort, D., \& Hillier, D. (2006). Corporate social responsibility and the UK construction industry. Journal of Corporate Real Estate, 83, 134-150. https://doi.org/10.1108/14630010610711757

Kim, S. (2011). Transferring Effects of CSR Strategy on Consumer Responses: The Synergistic Model of Corporate Communication Strategy. Journal of Public Relations Research, 23(2), 218-241. https://doi.org/10.1080/1062726X.2011.555647

Kim, S., Haley, E., \& Schumann, D. W. (2009). Primary consequences of corporate communication strategy on consumer responses. American Academy of Advertising (AAA) Annual Conference, Cincinnati, $\mathrm{OH}$. 
Kotler, P., \& Lee, N. (2005).Corporate Social Responsibility: Doing the Most Good for Your Company and Your Cause. John Wiley \& Sons, Inc., Hoboken, New Jersey.

KPMG International Survey of Corporate Responsibility Reporting. (2008). Retrieved 8 December, 2018, from http://www.kpmg.com

Kumar, K., \& Subramanian, R. (1998). Meeting expectations of key stakeholders: stakeholder management in the health care industry. SAM Advanced Management Journal, 63, 31-41.

Levitt, T. (1958). The dangers of social responsibility. Harvard Business Review, September-October, 41-50.

Lim, J. S., \& Greenwood, C. A. (2017). Communicating corporate social responsibility (CSR): Stakeholder responsiveness and engagement strategy to achieve CSR goals. Public Relations Review. https://doi.org/10.1016/j.pubrev.2017.06.007

Lindblom, C. (1994). The implications of organizational legitimacy for corporate social performance and disclosure. Paper presented at the critical perspectives on accounting conference, New York.

Maich, S. (2004). Walmart's Mid Life Crisis, Maclean's, August 23, p. 45, "The People Make It All Happen," Discount Store News, October 1999, 103-106. Retrieved 12.01, 2014, from www.walmartstores.com

Marais, M. (2012). CEO rhetorical strategies for corporate social responsibility (CSR). Society and Business Review, Emeral, 7(3), 223-243. https://doi.org/10.1108/17465681211271314

Matten, D., \& Crane, A. (2005). Corporate citizenship: toward an extended theoretical conceptualization.Academy of Management Review, 30(1), 166-79. https://doi.org/10.5465/amr.2005.15281448

McWilliams, A., \& Siegel, D. (2001). Corporate social responsibility: a theory of the firm perspective. Academy of Management Review, 26, 117-27. https://doi.org/10.5465/amr.2001.4011987

Morrison, E., \& Bridwell, L. (2011). Consumer Social Responsibility - The True Corporate Social Responsibility. Competition Forum, 9(1), 144-149.

Morsing, M., \& Schultz, M. (2006). Corporate social responsibility communication: stakeholder information, response and involvement strategies. Business Ethics: A European Review, 15(4), 323-338. https://doi.org/10.1111/j.1467-8608.2006.00460.x

Morsing, M. (2006). Corporate social responsibility as strategic auto-communication: on the role of external stakeholders for member identification. Business Ethics: A European Review, 15(2), 171-182. https://doi.org/10.1111/j.1467-8608.2006.00440.x

Morsing, M. (2018). CSR Communication: What Is It? Why Is It Important? In Corporate Social Responsibility. https://doi.org/10.1017/9781316335529.018

Morsing, M., Schultz, M., \& Nielsen. (2008). The 'Catch 22' of communicating CSR: Findings from a Danish study. Journal of Marketing Communications, 14(2), 97-111. https://doi.org/10.1080/13527260701856608

Nestlé in society (2012). Creating Shared Value and meeting our commitments. Retrieved from http://www.csrwire.com/reports/1299-Nestl-in-Society-Creating-Shared-Value-and-meeting-our-commitments

Nike Sustainable Business Performance Report (2017-2018). Nike Inc.Retrieved 6th February, 2018, from www.nikeresponsibility.com

Perks, K. J., Farache, F., Shukla, P., \& Berry, A. (2013). Communicating responsibility-practicing irresponsibility in CSR advertisements. Journal of Business Research, (66), 1881-1888. https://doi.org/10.1016/j.jbusres.2013.02.009

Popoli, P. (2011). Linking CSR strategy and brand image: Different approaches in local and global markets, Marketing Theory. SAGE Publication.Retrieved 10.02, 2014, from http://www.sagepublications.com

Porter ,M. E., \& Kramer, M. R. (2011). Creating shared value: Howto reinvent capitalism-And unleash a wave of innovation and growth. Harvard Business Review, 1-17.

Porter, M. E., \& Kramer, M. R. (2002).The competitive advantage of corporate philanthropy.Harvard Business Review, 80(12), 57-68.

Post, J. E. et al. (1996). Business And Society: CoporateStragey, Public Policy, Ethics (pp.5,43,46). McGraw Hil Inc. New York. 
Post, J., Preston, L., \& Sachs, S. (eds., 2002). Redefining the Corporation: Stakeholder Management and Organizational Wealth. Stanford, CA: Stanford University Press.

Prado-lorenzo, J.-M., \& Garcia-sanchez, I.-M. (2010). The role of boards of directors in disseminating relevant information on greenhouse gases. Journal of Business Ethics, 97(3), 391-424. https://doi.org/10.1007/s10551-010-0515-0

Preston, A. M., Wright, C., \& Young, J. J. (1996). Imag [in] ing annual reports. Accounting, Organizations and Society, 21(1), 113-137. https://doi.org/10.1016/0361-3682(95)00032-5

Robbins, S. P., \& Coulter, M. K. (2012). Management(11th ed., pp. 124-125). Pearson Education, Inc., publishing as Prentice Hall, New Jersey, USA.

Robins, F. (2005). Why Corporate Social Responsibility Should Be Popularized but Not Imposed, (ed.) Proceedings of the European Academy of Management Conference, Munich.

Rowe, M. (2006). Reputation, relationships and risk: A CSR primer for ethics officers. Business and Society Review 111, 441-455. https://doi.org/10.1111/j.1467-8594.2006.00281.x

Sacconi, L., Blair, M., Freeman, R E., and Vercelli, A. (2011). Corporate Social Responsibility and Corporate Governance: The Contribution of Economic Theory and Related Disciplines. Palgrave Macmillan, NY: USA, p. xiv. https://doi.org/10.1057/9780230302112

Schumann, D. W., Hathcote, J. M., \& West, S. (1991). Corporate advertising in America: A review of published studies on use, measurement, and effectiveness. Journal of Advertising, 20, 35-56. https://doi.org/10.1080/00913367.1991.10673346

Schumpeter, J. A. (1911). Theory of Economic Development, (in ed. The Economics of Development and Planning, 31st Edition, M L Jhingan).

Sen, S., \& Bhattacharya, C. B. (2001). Does doing good always lead to doing better? Consumer reactions to corporate social responsibility. Journal of Marketing Research, 38, 43-62. https://doi.org/10.1509/jmkr.38.2.225.18838

Sen, S., Bhattacharya, C. B., \& Korschun, D. (2006). The role of corporate social responsibility in strengthening multiple stakeholder relationships: a field experiment. Journal of the Academy of Marketing Science, 34, 158-166. https://doi.org/10.1177/0092070305284978

Shambora, J. (2010). How I Got Started: Blake Mycoskie, Founder of TOMS Shoes, Fortune (March 22, p. 72).

Shuili, D., Bhattacharya, C. B., \& Sen, S. (2010). Maximizing Business Returns to Corporate Social Responsibility (CSR): The Role of CSR Communication. International Journal of Management Reviews, 12(1), 8-19. https://doi.org/10.1111/j.1468-2370.2009.00276.x

Sohn, Seok, Y., Jin K. H., Lee, \& Sung, H. (2012).Communication strategies for enhancing perceived fit in the CSR sponsorship context. International Journal of Advertising, 31(1), 133-147. https://doi.org/10.2501/IJA-31-1-133-146

Sones, M. (2007). Corporate citizenship and social responsibility: How effective are pharmaceutical companies communicating these business initiatives? A paper presented at the annual meeting of the Association for Education in Journalism and Mass Communication. (2007). The Renaissance, Washington DC, 8 August 2007. Retrieved from http://www.allacademic.com (accessed on 17.02.2017)

Sony Annual Report (2013). Business and CSR Review. Retrieved 6th February, 2016, from http://www.sony.net/SonyInfo/csr_report/about/

Steers, R. M. et al. (1985). Managing Effective Organization: An Introduction (p. 626). Boston, Kent Publishing Company.

Stone, B. (2001). Corporate social responsibility and institutional investment: a content analysis-based portfolio screening model for socially responsible mutual funds. Business and Society, 40, 112-7. https://doi.org/10.1177/000765030104000107

Stoner, J. A. F. et al. (1997). Management (6th ed., pp.10-104). Prentice Hall of India.

Stuart, H. (2006). Corporate social responsibility: How to act and what to communicate. Retrieved 22 December, 2013, from http://smib.vuw.ac.nz:8081/www/ANZMAC2006/documents/Stuart_Helen.pdf 
Suchman, M. C. (1995). Managing legitimacy: Strategic and institutional approaches. Academy of Management Review, 20(3), 571-610. https://doi.org/10.5465/amr.1995.9508080331

Sustainability Report. (2013). Virgin Atlantic. Retrieved 7th February, 2014, from virginatlantic.com/changeisintheair

Takano, K. (2017). CSR communication in Japan: the case of Kikkoman. Corporate Communications. https://doi.org/10.1108/CCIJ-02-2016-0017

The Economist (2005). 22 January, p. 11

The Economist (2008). Special report on 19 January, p. 3, 21

Timmins, K. J. (2004). Corporate Social Responsibility: Implications for Small and Medium Enterprises in Developing Countries". June, UNIDO Study Paper.

Trochim, W., \& Donnelly, J. P. (2007).The Research Methods Knowledge Base (3rd ed.). Atomic Dog Publishing, Mason, USA.

Turban, D. B., \& Greening, D. W. (1997). Corporate social performance and organizational attractiveness to prospective employees. Academy of Management Journal, 40, 658-672. https://doi.org/10.2307/257057

USA Today. (2014). Acebook's Mark Zuckerberg biggest giver in 2013. Retrieved 10th February, 2016, from http://www.usatoday.com

Wal-Mart. ( 2006). [www.walmartstores.com], March 16, 2006; and an advertisement from USA Today, March 6, 2006, p. 5A.

Walmart Global Sustainability Report (2013). Retrieved from http://corporate.walmart.com (Accessed on 6th February, 2014)

Wanderley, L. S. O., Lucian, R., Farache, F., \& Filho, J. M. de S. (2008). CSR Information Disclosure on the Web: A Context-Based Approach Analysing the Influence of Country of Origin and Industry Sector. Journal of Business Ethics, 82(2), 369-378. https://doi.org/10.1007/s10551-008-9892-z

Werther, W. B., \& Chandler, D. (2006). Strategic Corporate Social Responsibility: Stakeholders in a Global Environment. Sage Publications: New Delhi.

Whitehouse, L. (2006). Corporate Social Responsibility - Views from the Frontline. Journal of Ethics, 63, 279-96. https://doi.org/10.1007/s10551-005-3243-0

Windell, K. (2006). Corporate Social Responsibility Under Construction: Ideas, Translations, and Institutional Change. Uppsala University, Uppsala.

Zappalà, G., \& Cronin, C. (2002). The employee dimensions of Corporate Community Involvement in Australia: Trends and prospects - Australian and New Zealand Third Sector Research, Sixth, 2002 - anztsr.org.au... This view is supported by a recent study that argued that corporate community involvement had 'come of age' in Australia (Cronin \& Zappalà 2002), pp.1-2.

Ziek, P. (2009). Making sense of CSR communication. Journal of Corporate Social Responsibility and Environmental Management, 16(3), 137-145. https://doi.org/10.1002/csr.183

Zikmund, W. G., Babin, B. J., Carr, J. C., \& Griffin, M. (2010). Business Research Methods (9th ed.). South-Western CINAGAGE Learning, Mason, USA. 